\title{
القصد في القر آن الكريم بين التكويني والتشريعي: مقاربة مقاصدية
}

\section{عبد الززاق وورقية}

مقدمة:

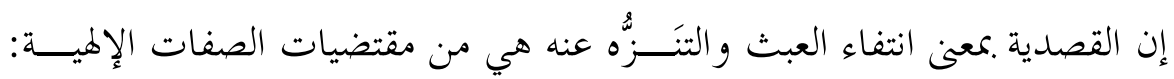

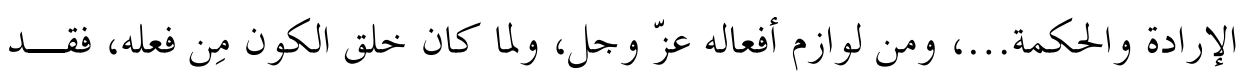

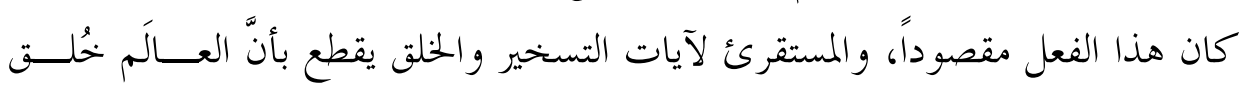

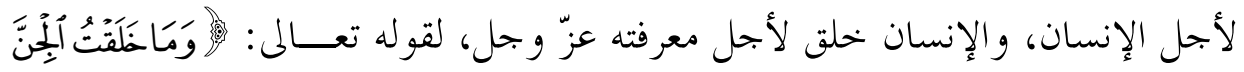

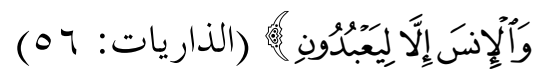

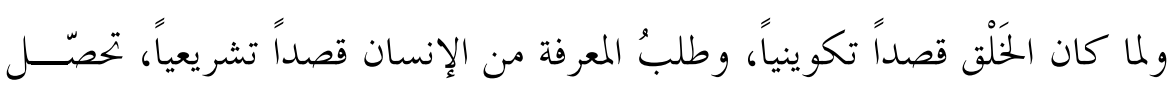

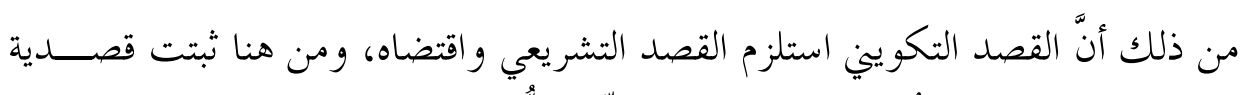

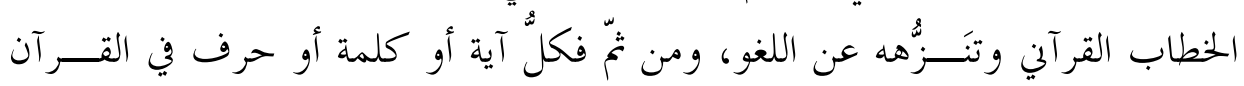

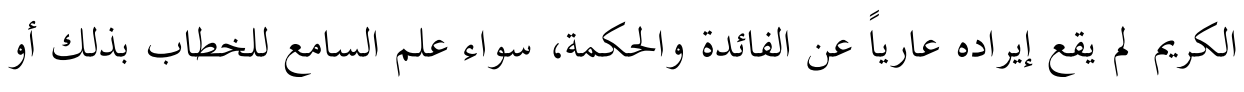

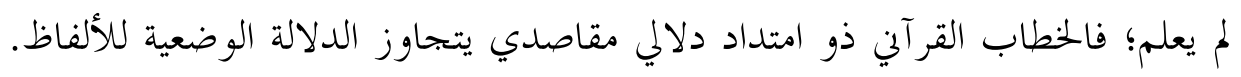

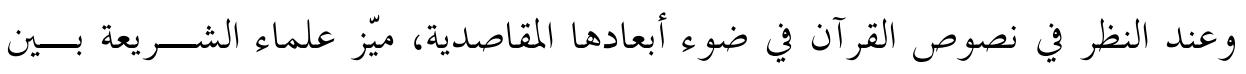

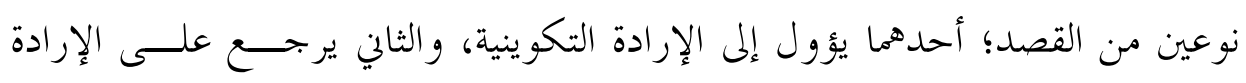

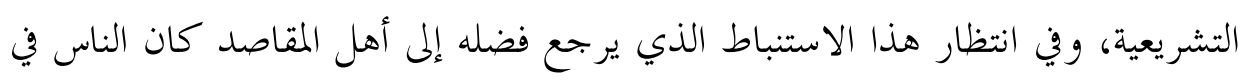

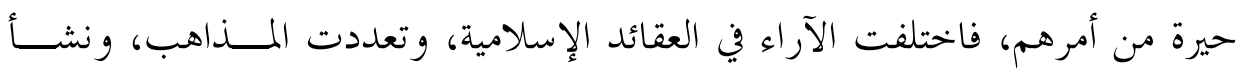

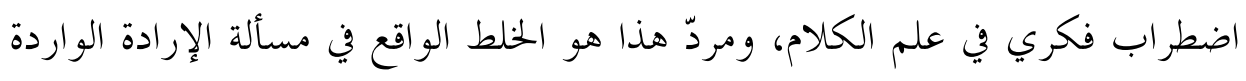

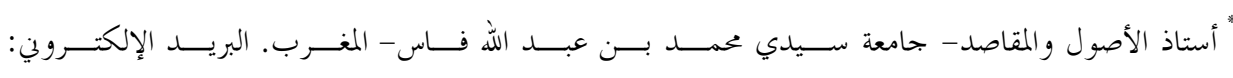
ourkia@gmail.com 


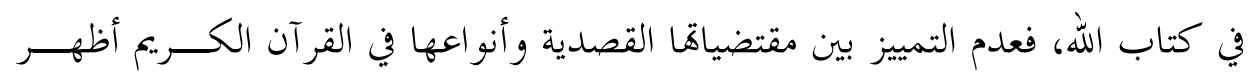

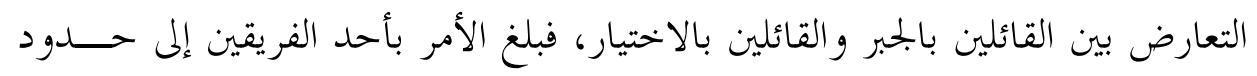

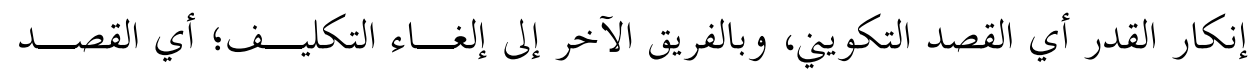

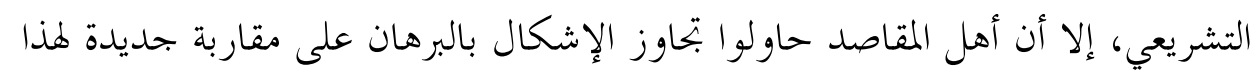

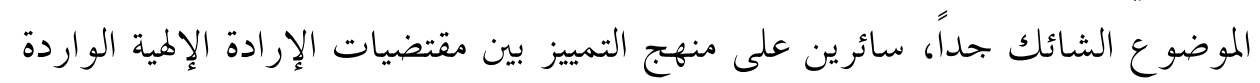

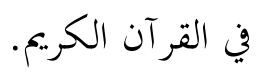

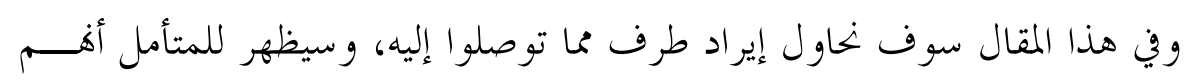

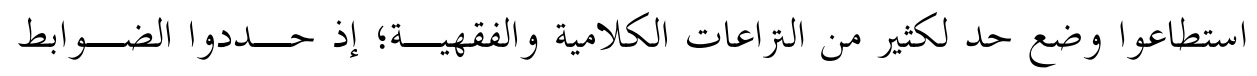

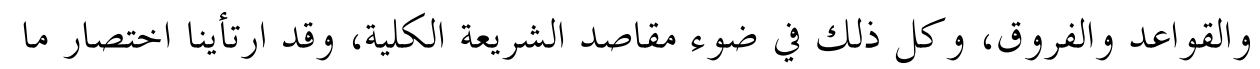

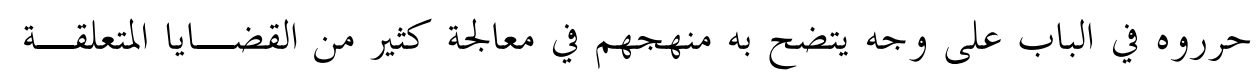

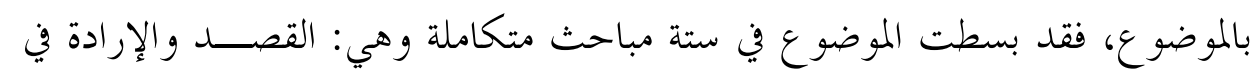

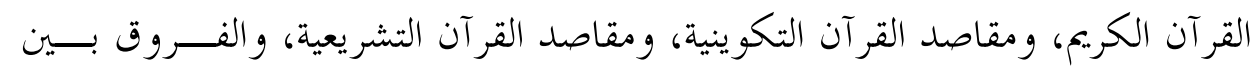

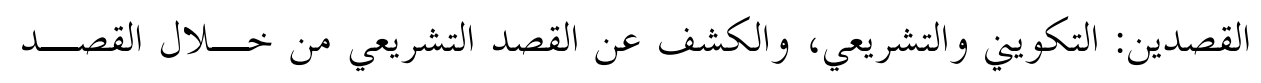
التكويني، وبعض المقتضيات الدلالية للمقاصد القرآية.

\section{أولاً: القصد والإرادة في القر آن الكريم}

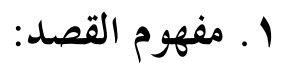

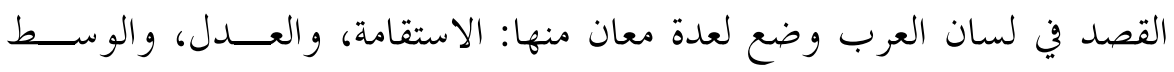

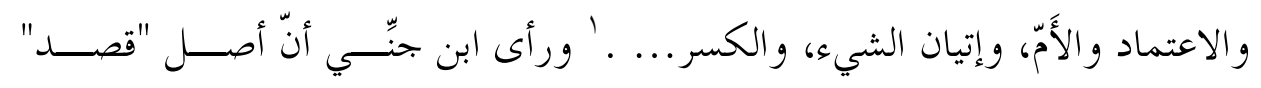

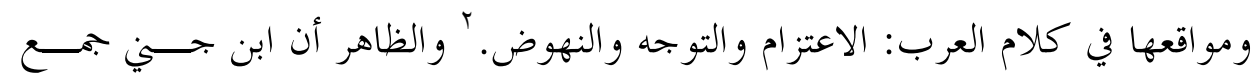

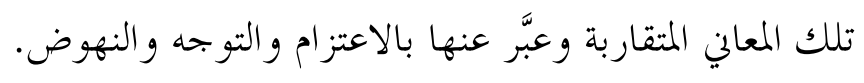

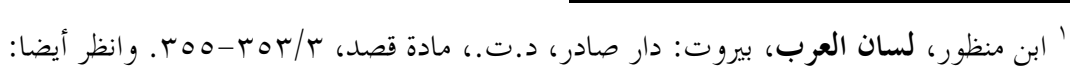

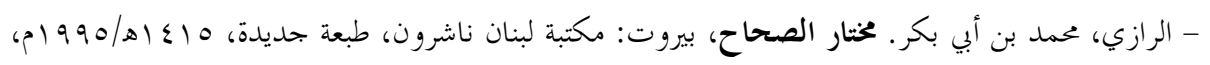

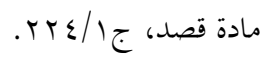

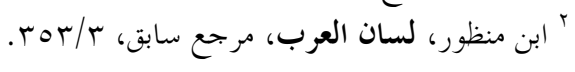


فإذا عُرّف القصد بأنه التوجه والاعتزام، فالمقصد مصدر منه أي المتوجه إليه، ومنه

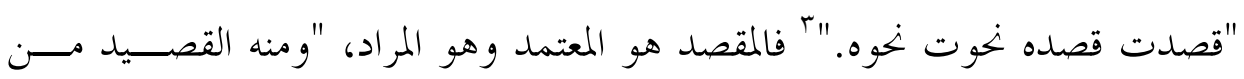
الشعر، قال ابن جي: سمي قصيداً لأنه قصد و اعتمد و إن كان ما قصر منه و اضـــــ

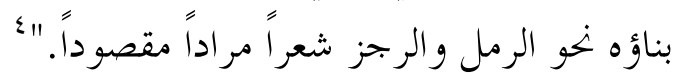

وأما من حيث الاصطلاح الشرعي، فقد توجه لفظ القصد إلى عدة معان أبرزها:

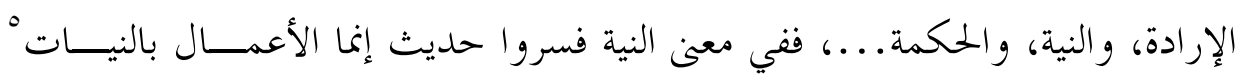
بالقاعدة الفقهية الكبرى: "الأمور .كقاصدها،" "ج ومن ثم أكدو أن أن حقيقة النيـــة هــي القصد.

و وي معنى الإرادة، فقد ورد عند أهل العقائد في سياق إثبات الإرادة لله تعالى: "أن المريد هو القاصد لوقوع أحد طرفي الممكن، "م وبرهنوا على أن "لا مرجح لاختصاص

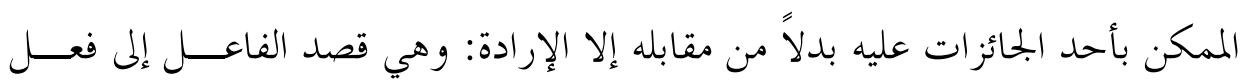
ذلك الجائز.

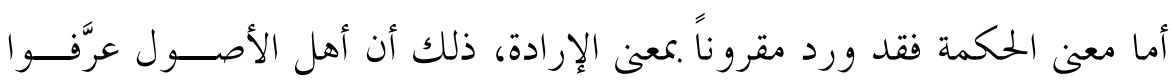
المقاصد الشرعية بالمعاني والحكم المرادة من قبل الشارع، قال العلامة ابــن عاشـــور:

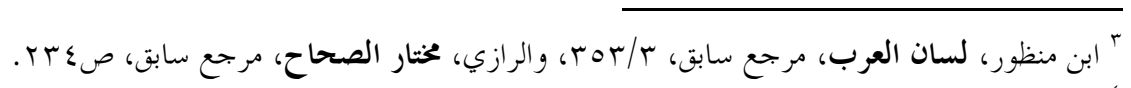

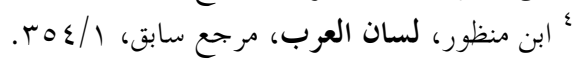

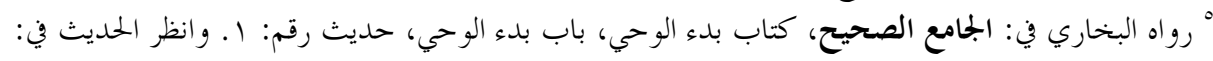

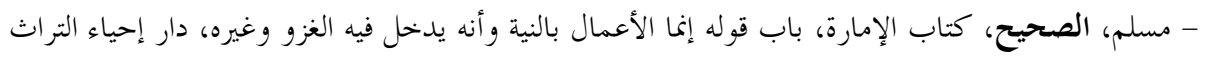

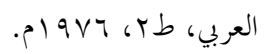

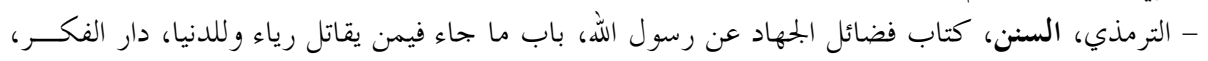

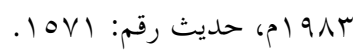

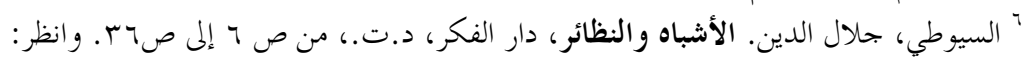

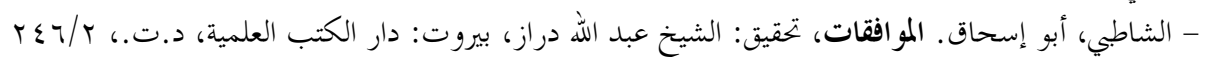
فما بعدها.

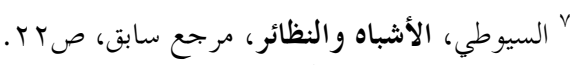

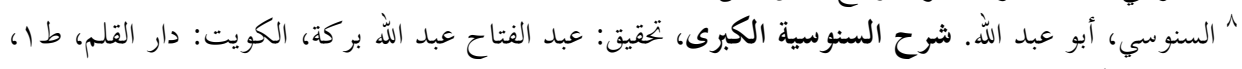

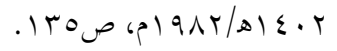

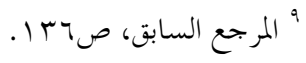




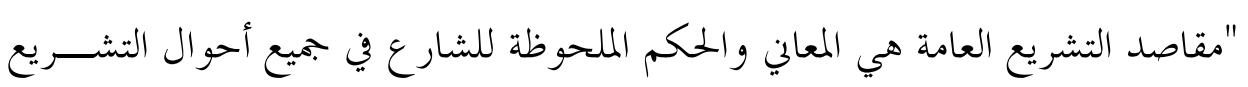

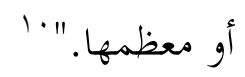

ومن هنا يتبين أنَّ قصد الشرع هو إرادته، ومقاصد الشرع هي حكمه ومعانيـهـ

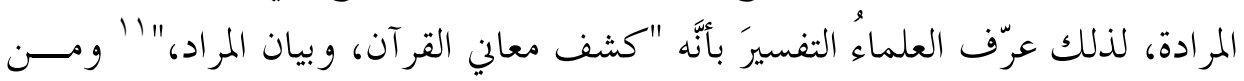

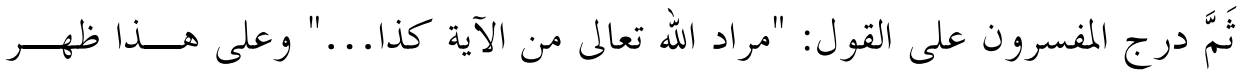

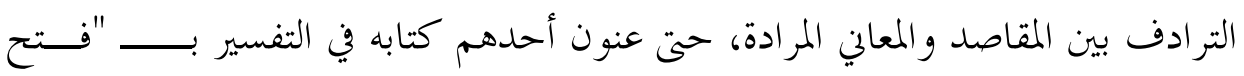

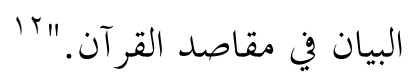

و وحلاصة القول: إن القصد في اصطلاح أهل الشرع يرجع إلى معنيين بــارزين،

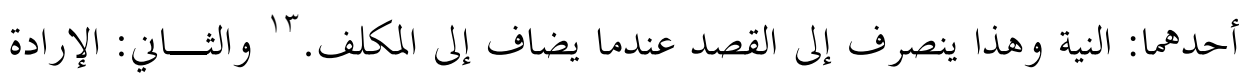

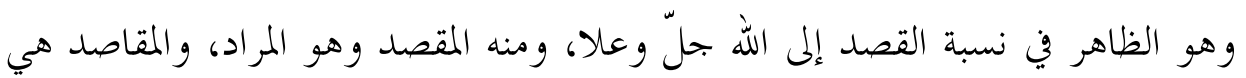
المعاني والحكم المرادة. ومن ثم يكون البحث في مقاصد القرآن هو في الأساس بحث في مر اداته، وتتنوع مقاصد القرآن بتنوع مراداته، فالقصد في القرآن الكريم تابع للإرادة.

\section{ץ. القصد والإرادة في القر آن الكريم:}

أثبت جهمور أهل الكام صفة الإرادة لله تعالى، وقالوا: "ويجب أن يُعلـــــ أن الله

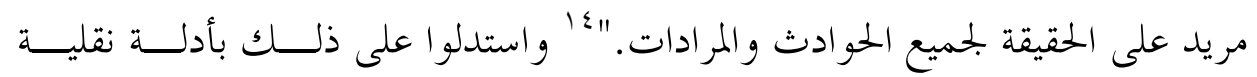
وأخرى عقلية: - مريل

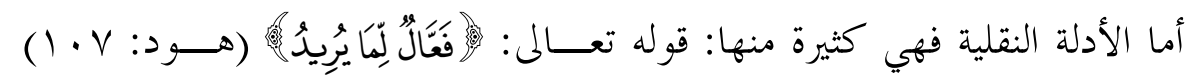

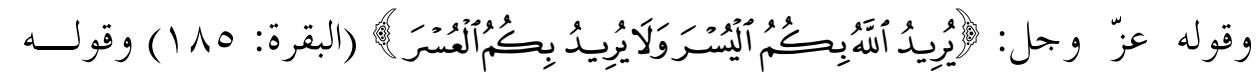

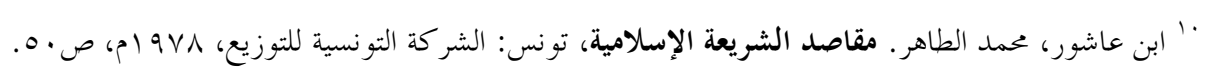

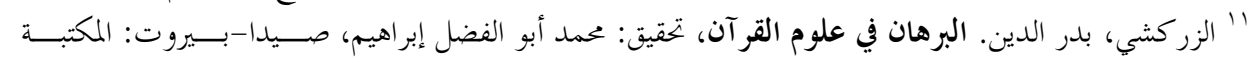

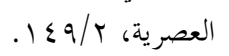

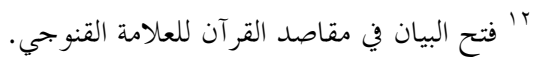

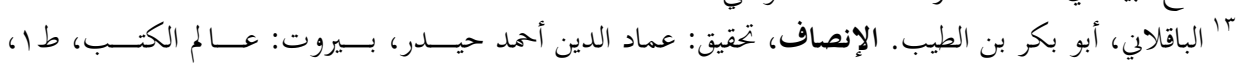

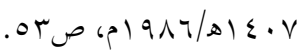

$$
\begin{aligned}
& \text { ء' المرجع السابق، صـهـه }
\end{aligned}
$$




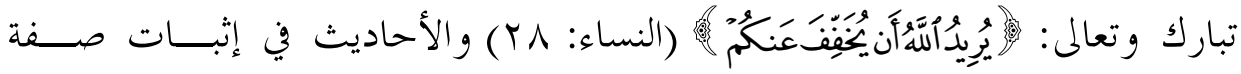
الإرادة للباري تعالى كثيرة.

$$
\text { ومن الأدلة العقلية التي أوردوها على إثبات الإرادة: }
$$

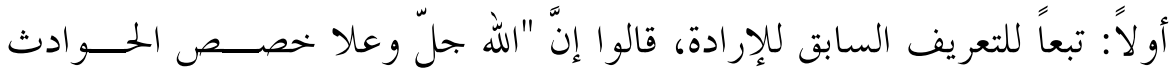

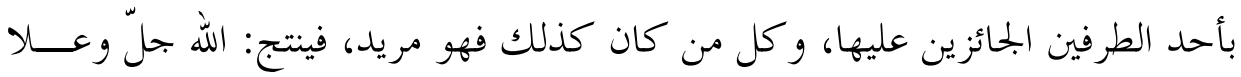

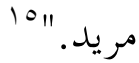

ثانياً: ما ثبت من ترتيب الأفعال و اختصاصها بوقت دون وقتـت، ومكــــان دون

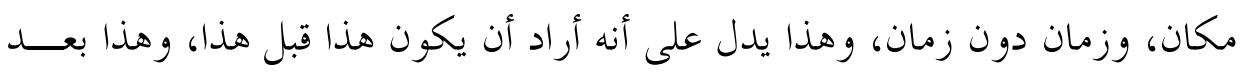

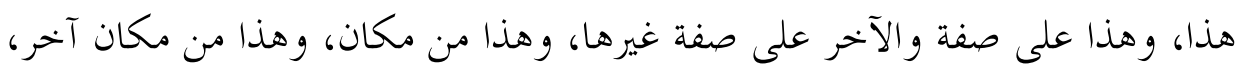
إلى غير ذلك.

ثالثاً: إنَّ المَلِك إذا جرى في مُلْكِه ما لا يريد، دلَّ ذلك على نقصه أو ضــعفه أو

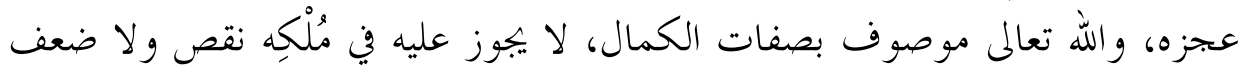
ولا عجز.

هكذا ثبتت صفة الإرادة عند أهل الكلام انطلاقاً من أدلة القرآن الكريم القطعية،

$$
\text { فضلاً عن شو اهد العقل المؤيدة. }
$$

إلا أنَّ المعتزلة أثناروا قضية خطيرة في علم العقائد كانـــت الســبـب في تلقيبـــمه

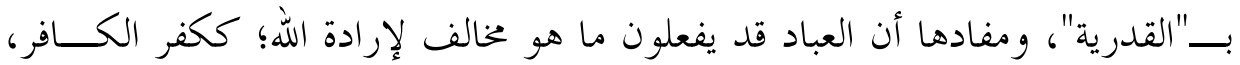

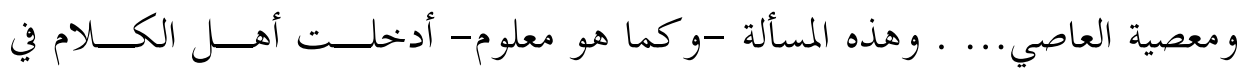
مناقشات حول القضاء والقدر، وقضايا التخيير والتسيير، وما إلى ذلك من الأمور التي

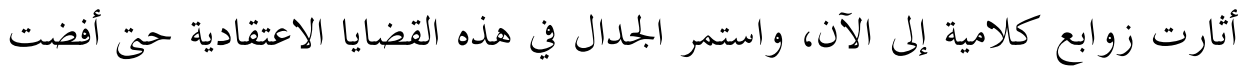

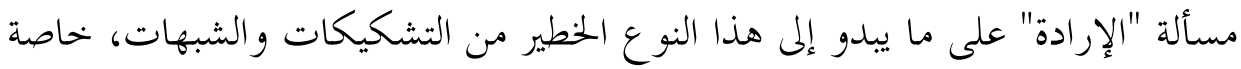

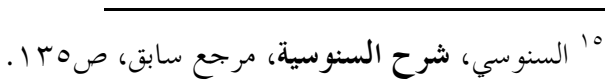

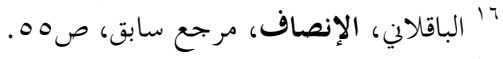

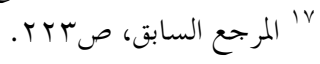




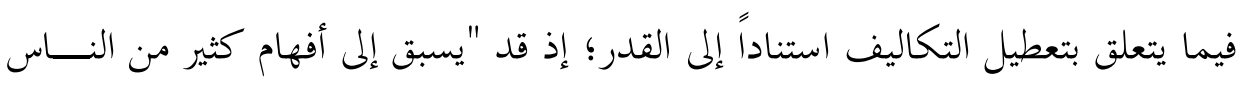

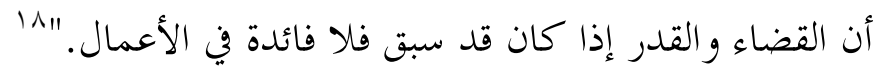

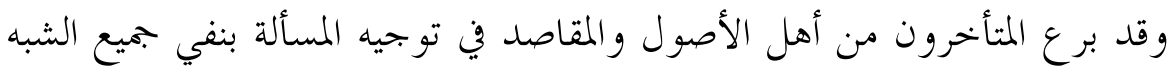

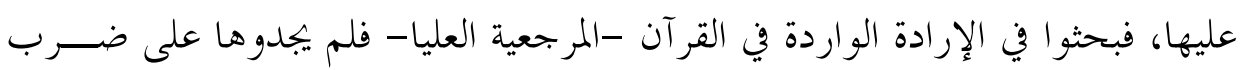
واحد، وإنما هي على ضربين باعتبار مقتضياها ومتعلقاها:

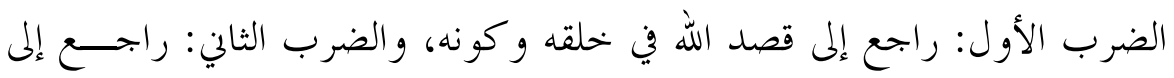

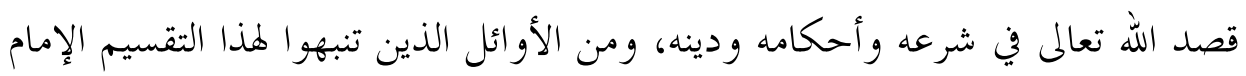

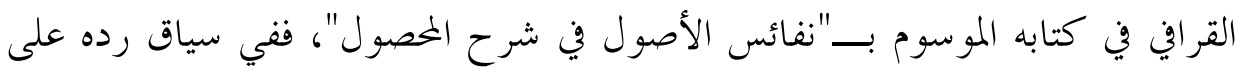

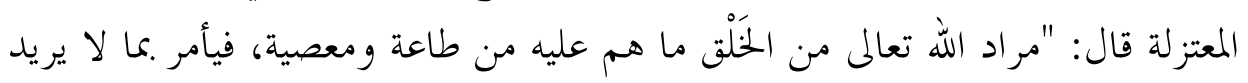

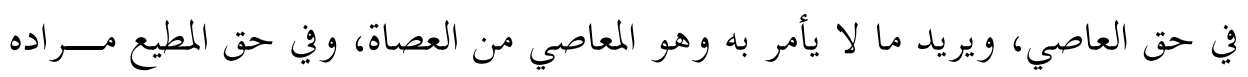

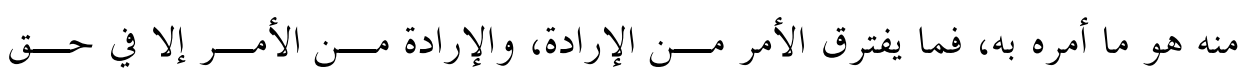

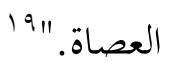

فو اضح من هذا القول أنه يقصد بــالأمر الإرادة التشــــيعية، وبـــالإرادة الإرادة

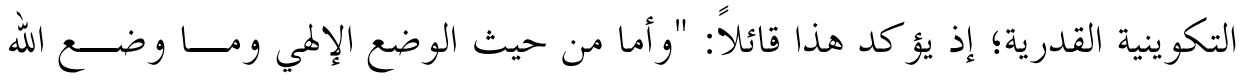

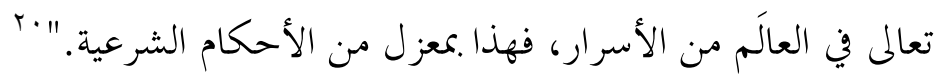

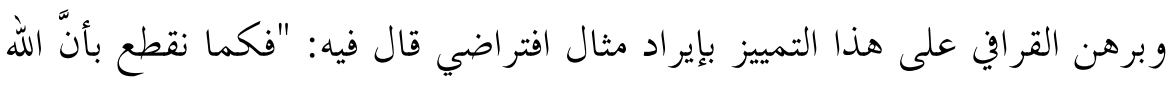

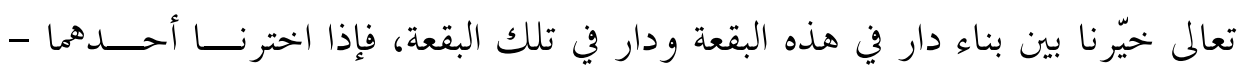

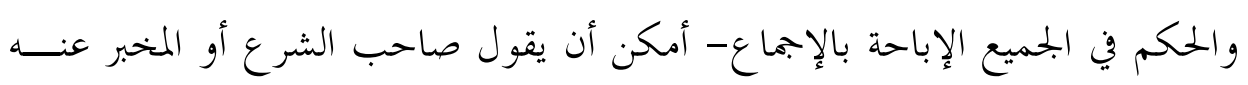

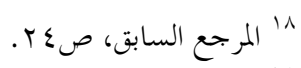

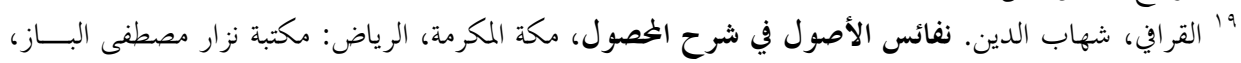

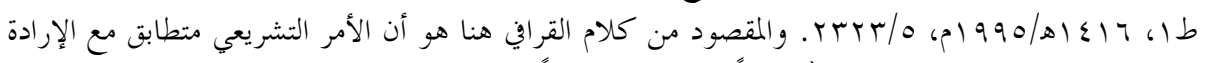

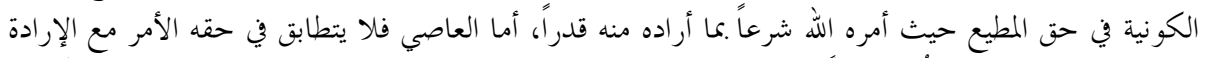

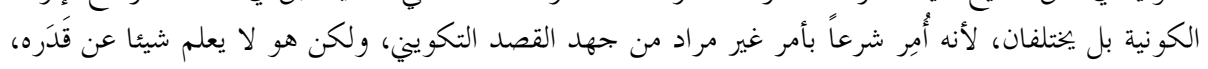

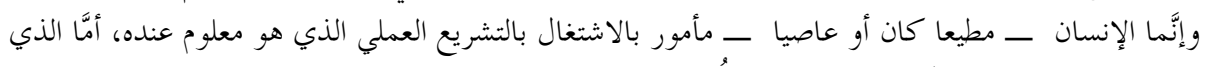

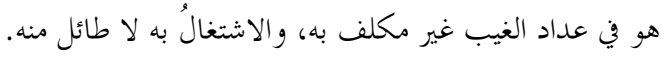

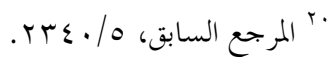


أصبتم في اختيار هذه البقعة للبناء، ولو اخترتم تلك البقعة، لكانت الدار مشؤومة، فإن

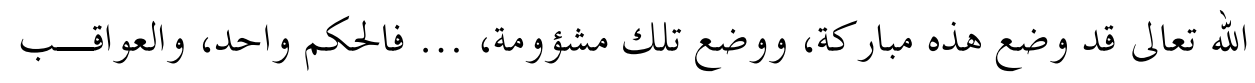

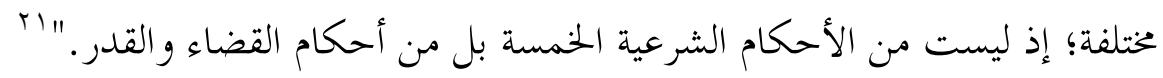
فتقريره هذا يدل على أن هناك أحكاماً قدرية كونية راجعة إلى الإرادة القدريــة، وهناك الأحكام الشرعية الراجعة إلى الإرادة التشريعية.

وهذا التفريق نفسه اتخذه العلامة ابن القيم موضوعاً لكتابه النفيس "شفاء العليل"،

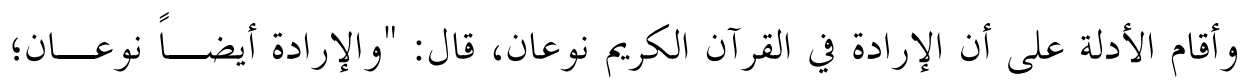

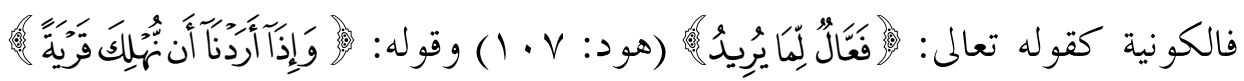

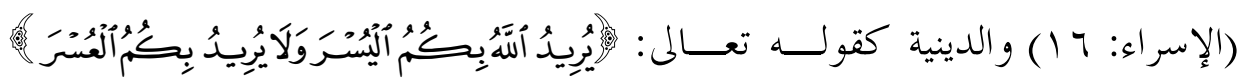

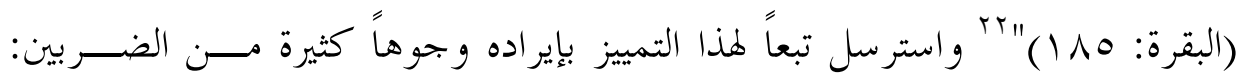
كالحكم و القضاء و الكتابة والأمر ... إلى غير ذلك من مقتضيات النوعين التي ســيأتي تفصيلها إن شاء الله.

واستطاع الشاطبي كذلك توجيه كثير من المسائل المقاصدية بالاهتـــــاء إلى هـــــا التقسيم؛ إذ قال: "إن الإرادة جاءت في الشريعة على معنيين، أحدهما: الإرادة الخلقيـــة

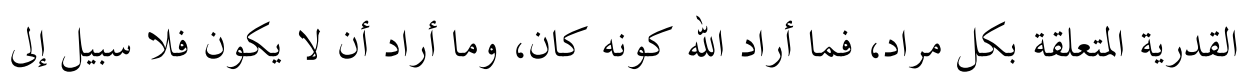

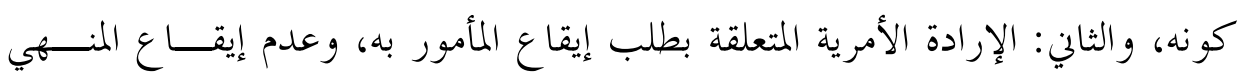

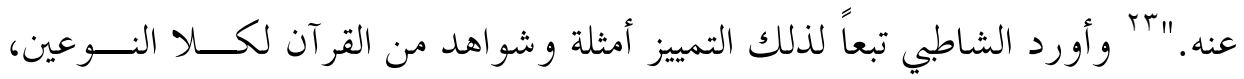
وأشار إلى أفا كثيرة جداً.

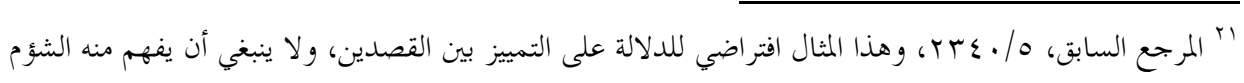

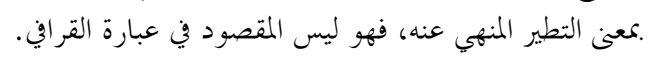

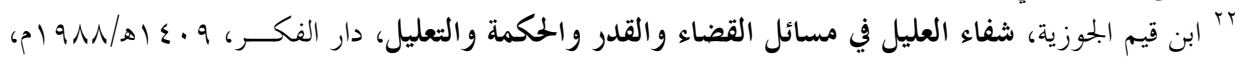

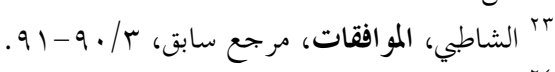

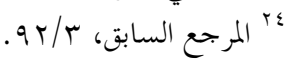


و بناء على هذا يتأكد الفرق بين إرادتين؛ أي بين قصدين: القصد الكولي و القصد

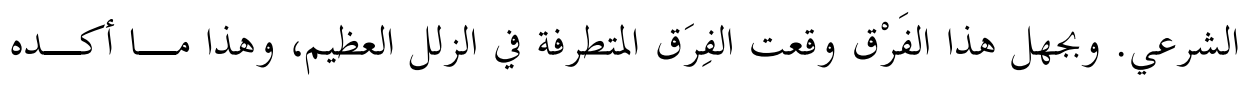

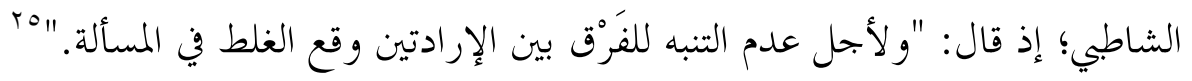
وبحدر الإشارة إلى أنه -حسب علمي - قلما ردَّ المتكلمون من أهل السنة ببيــان

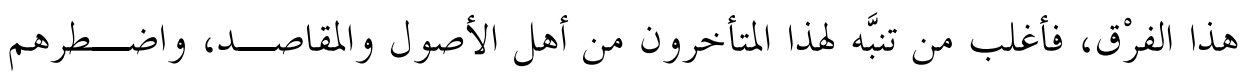

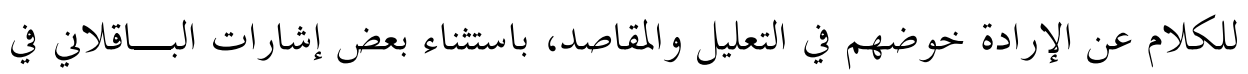

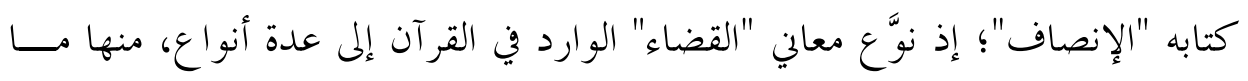

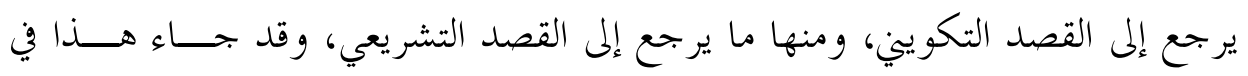

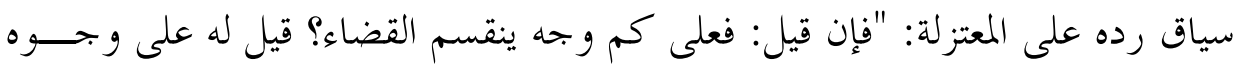

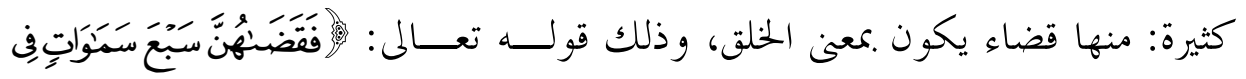

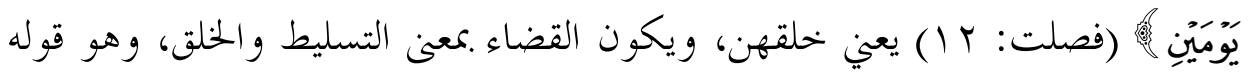

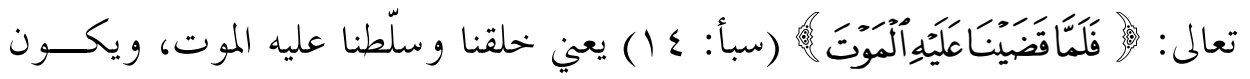

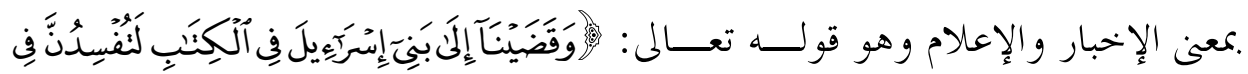

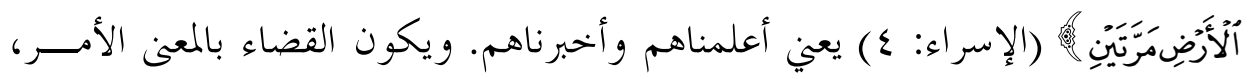

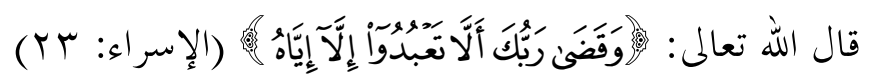

ويكون القضاء.معنى الحكم والإلزام، يقال: قضى القاضي على فلان بكــــا، أي

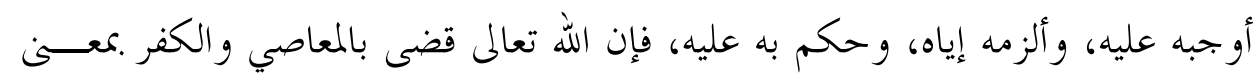

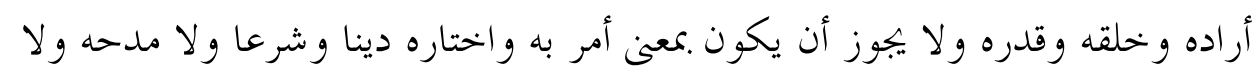

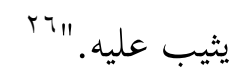

وأكد الباقلاني كذلك على أن غياب مثل هذا التمييز مدعاة للوقوع في تلبــيس

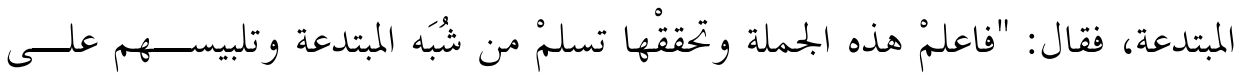

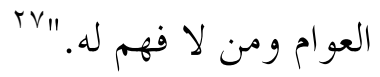

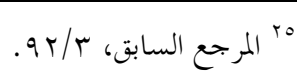

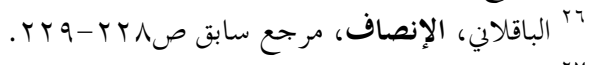

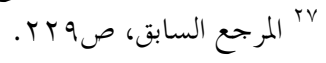




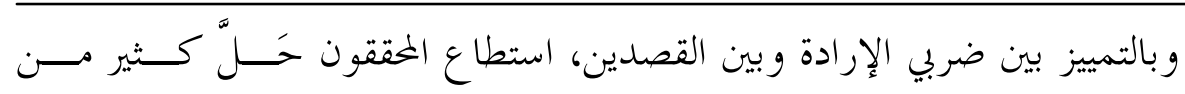

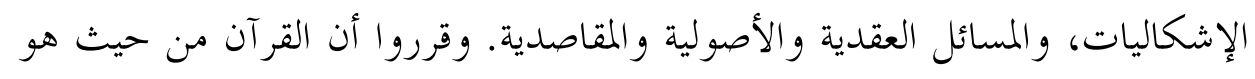

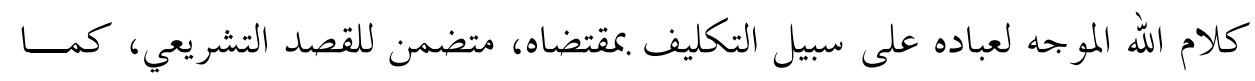
هو مخبر عن القصد التكويني، ما يعني أن هناك مقاصد قرآنية تشريعية، وأخرى كونية.

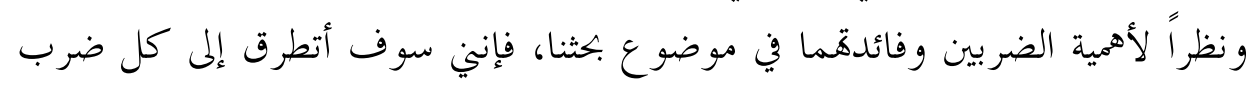

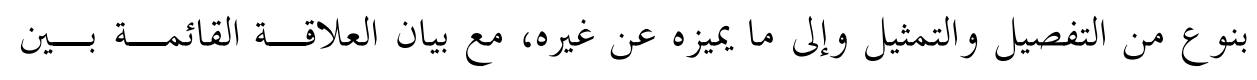
النوعين.

\section{ثانياً: مقاصد القر آن التكوينية}

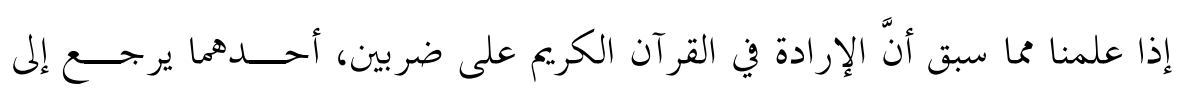

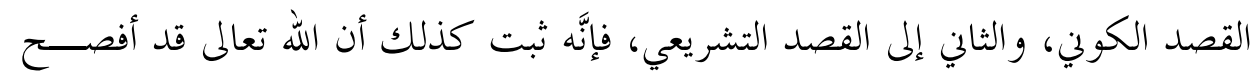

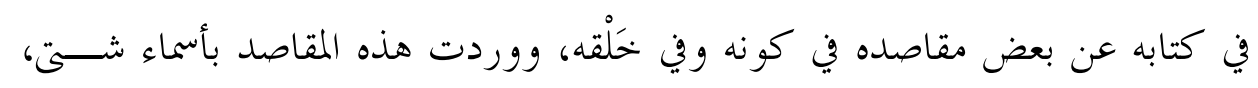
وعلى قدر تعدد الأسماء تعددت أنواع المقاصد التكوينية. ومن هذه الألفاظ التي عبَّ هـا القرآن الكريم عن هذه الأنواع: الإرادة، والقضاء،

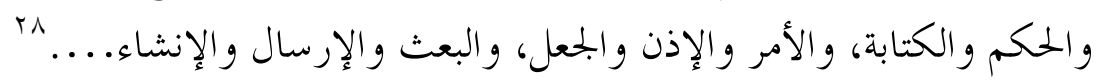

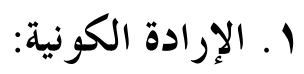

وهي الأصل في كل هذه الأنواع؛ إذ إنّ الله تعالى - كما ثبت سابقاً- يريد شرعاً

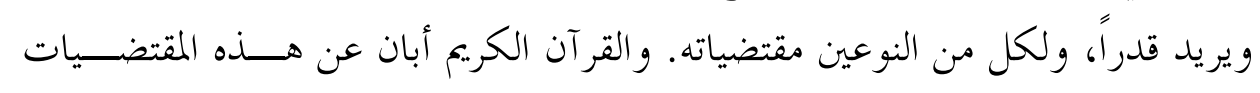

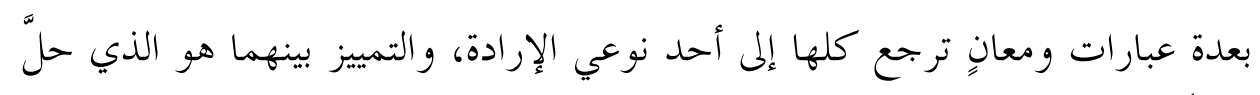

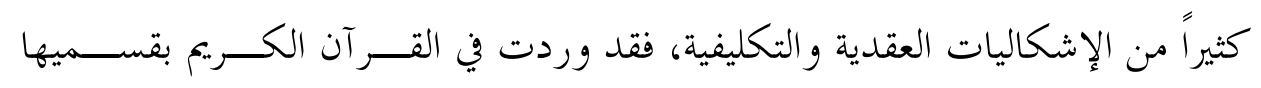
الشرعي و الكوني.

^r والمعول عليه في هذه الأنواع هو ما أورده العلامة ابن قيم الجوزية في كتابه شفاء العليل، والإمام الشــاطبي في كتابه الموافقات. 


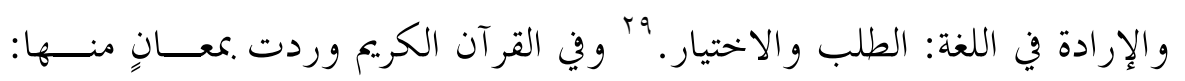

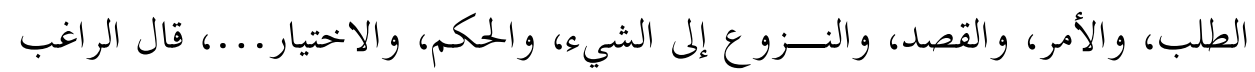

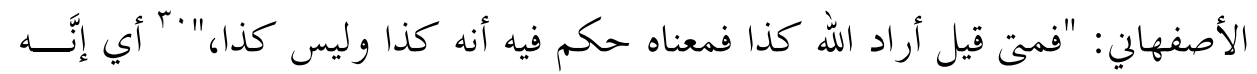

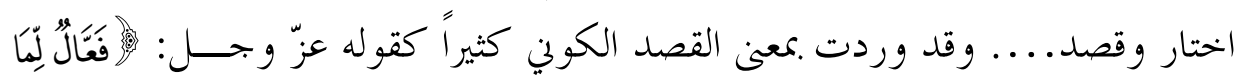

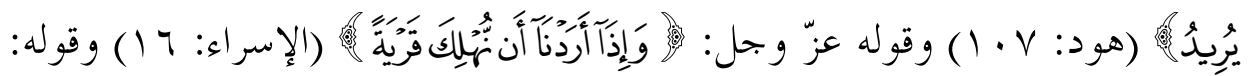

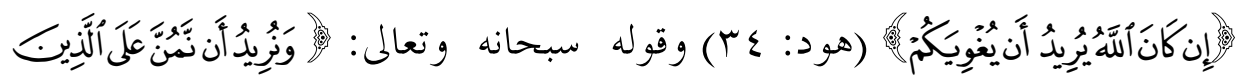

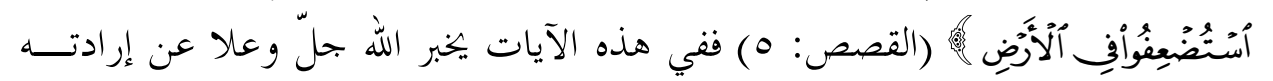

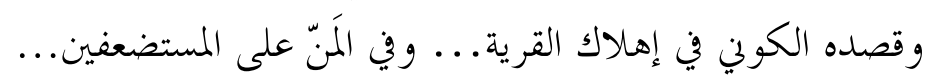

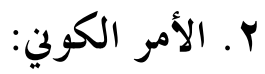

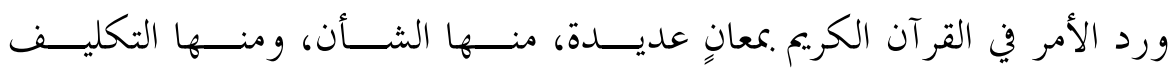

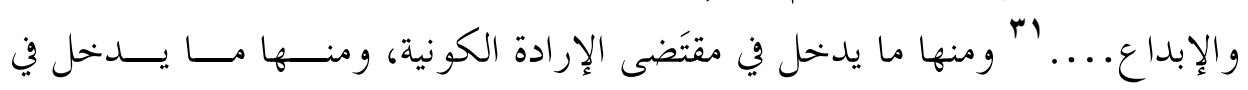
مقتضى الإر ادة التشريعية. فالأمر الكولي كقوله تعالى

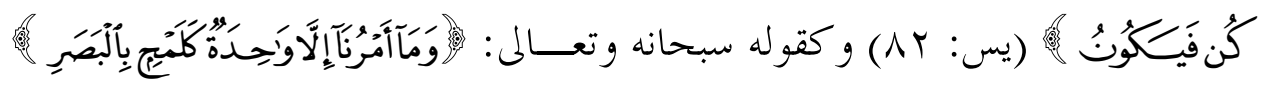

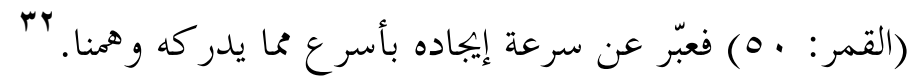

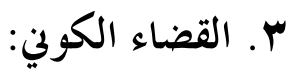

ورد القضاء في القرآن الكريم بعدة معالٍ كذلك، وأهمها المعنى الموافــق لمقتضــى

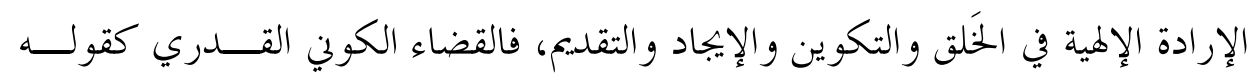

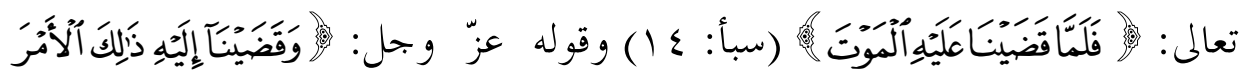

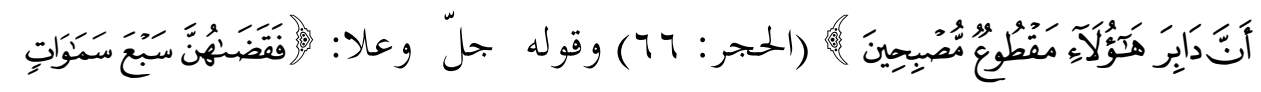

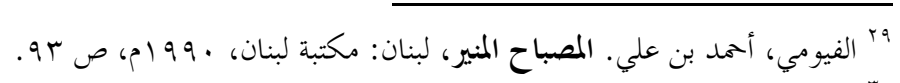

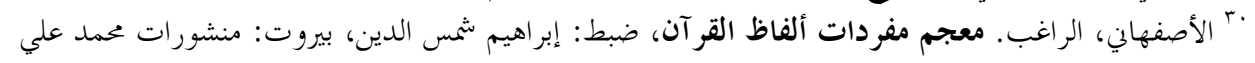

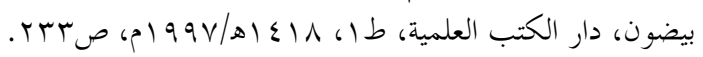

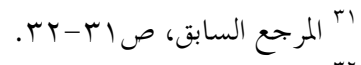

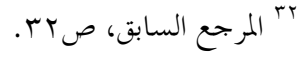




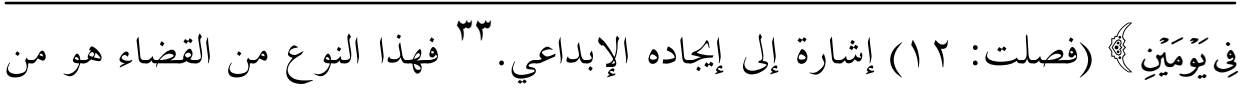

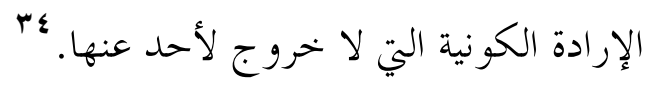

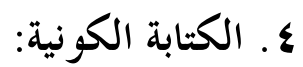

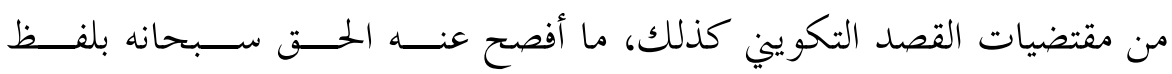

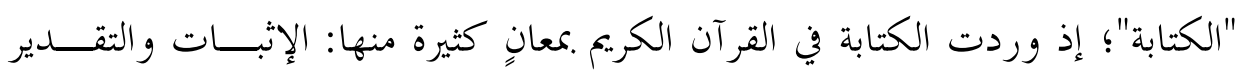

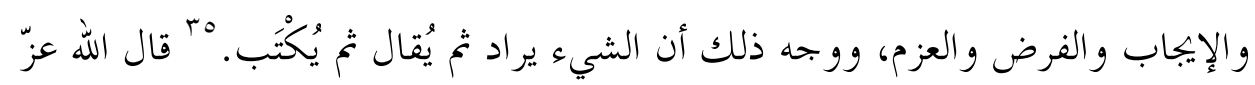

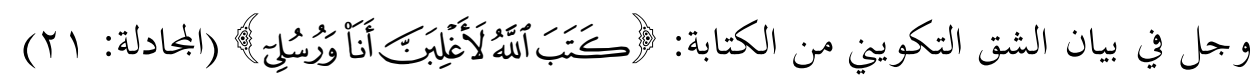

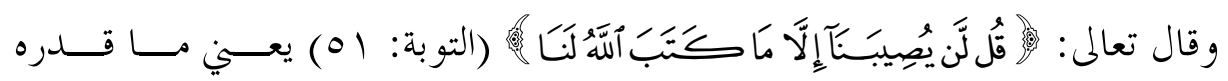
وقضاه.

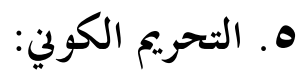

التحريم في اللغة: المنع، "والممنوع يسمى حراما" لَّ" وقد جاء في القرآن الكريم هذا المعنى، و منه ما يرجع إلى القصد الكوني، ومنه ما يرجع إلى القصد الشرعي، وقد ميسـز

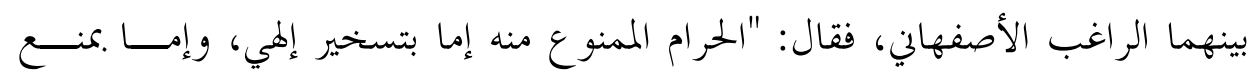

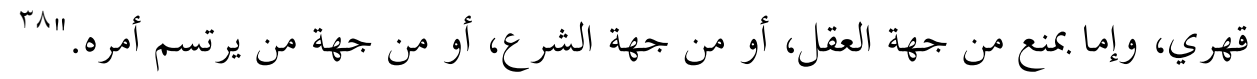

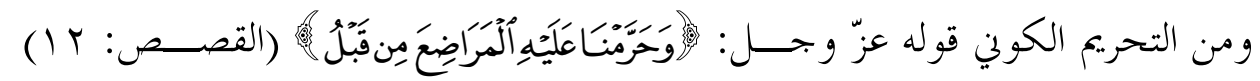

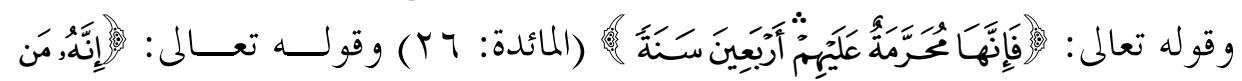

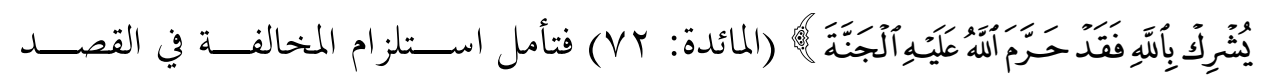
التشريعي للمعاقبة في القصد التكويني.

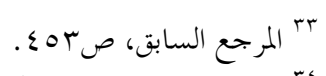

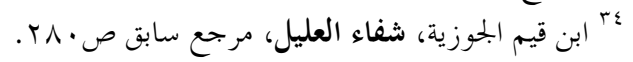

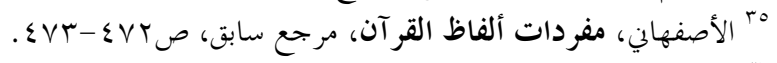

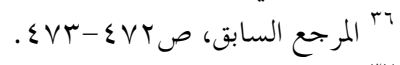
ل

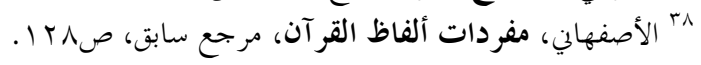




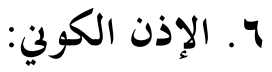

ومن مقتضيات إر ادته ومشيئته -سبحانه- وقصده، إذنه عزّ وجل، و ومنه الكــــوني و ومنه الشرعي، واستعمل في القرآن الكريم .معالٍ عدة منها: الإرادة، والأمر، والمشــيئة، و الرضا....، ومعلوم أها كلها راجعة إلى الإرادة بضربيها، فمن الإذن الكولي: قوله عزّ

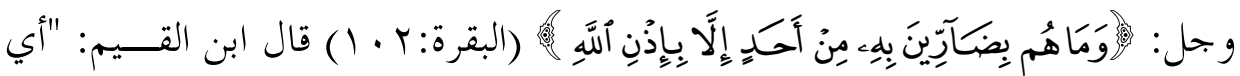

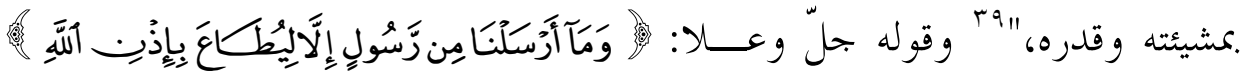

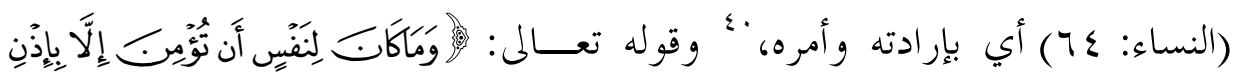

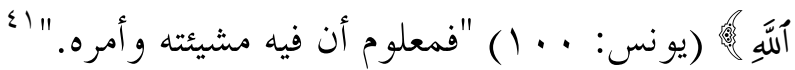

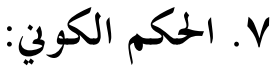

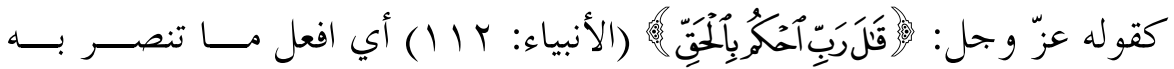

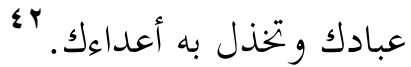

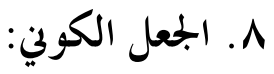

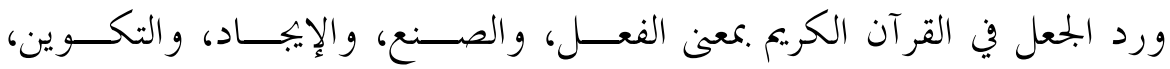

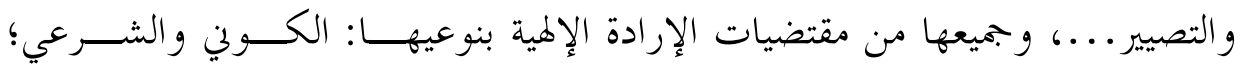

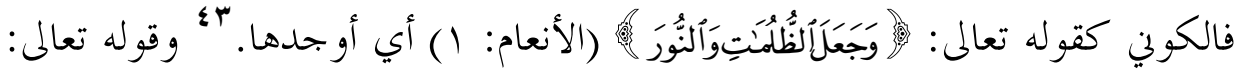

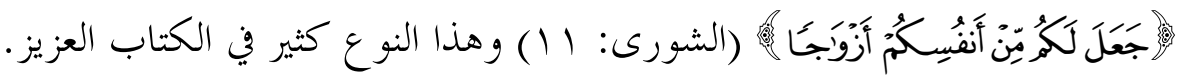

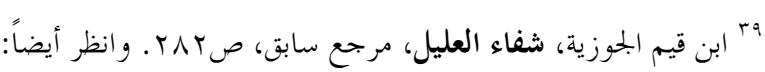

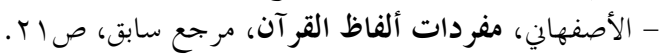

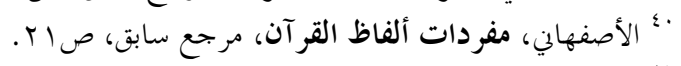

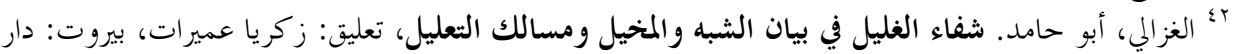

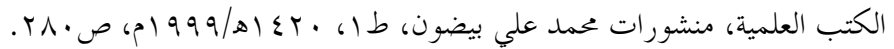

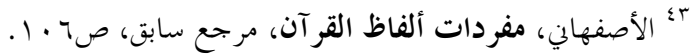




\section{9 ـ البعث الكولي:}

البعث في القرآن الكريم قصد به التوجيه، والإيجاد، و التقييض، و التسيير......

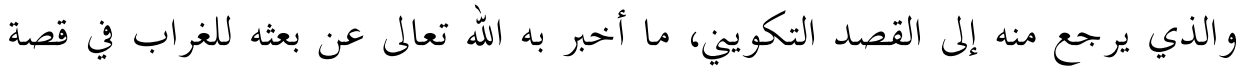

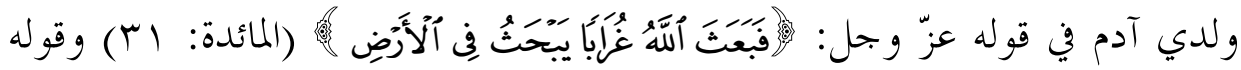

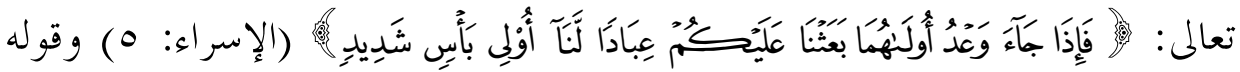

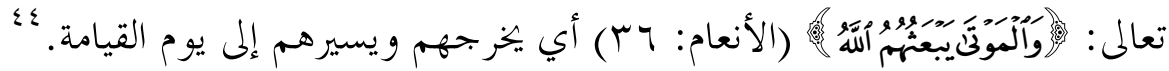

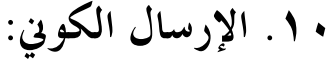

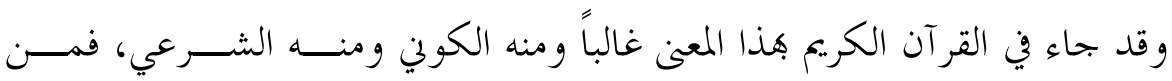

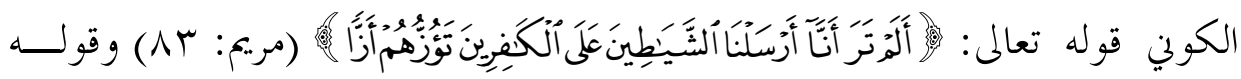

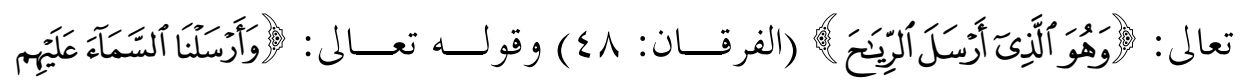

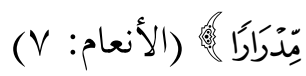

\section{ثالثاً: مقاصد القر آن التشريعية}

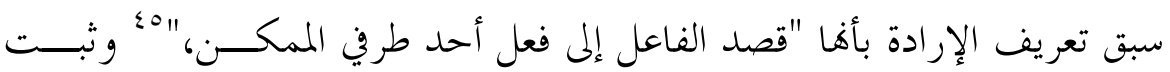
بذلك أنَّ القصد مطابق لإرادة عندما يضاف إلى الشرع، وعليه يصبح القصد الشرعي

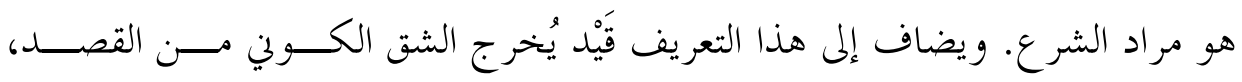
فيصبح القصد الشرعي هو مراد الشارع من خَلْقه من جهة الدين، وعلى هذا التعريف

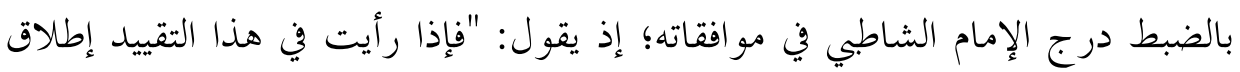

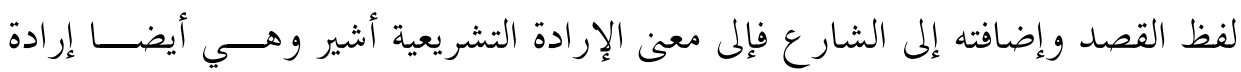
التكليف." آك فيدخل في مراد الشرع الأحكام الشرعية ومقاصدها؛ إذ "الشريعة أحكام تنطوي على مقاصد ومقاصد تنطوي على أحكام. "Vاء

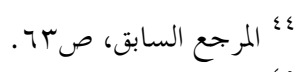

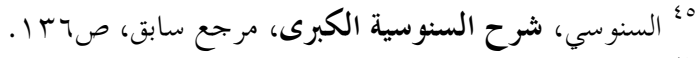

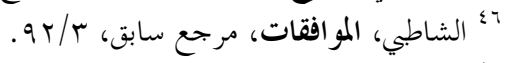

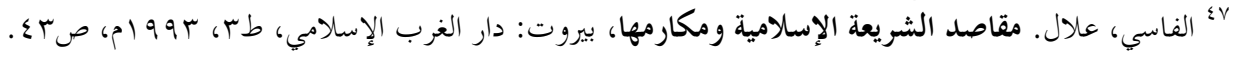


وهذا القصد التشريعي أبان عنه القرآن الكريم بطرق كثيرة، وبأساليب وألفــاظ

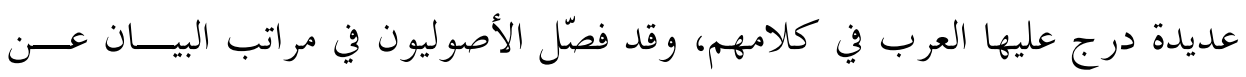

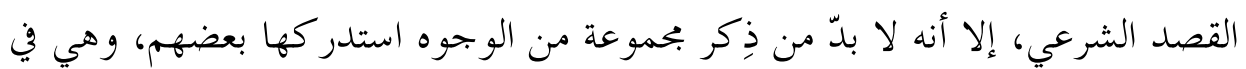

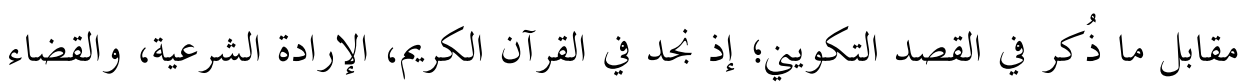

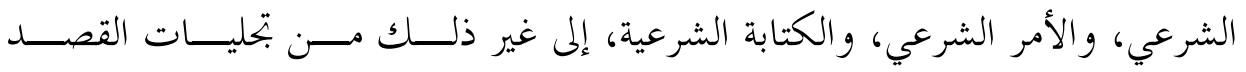

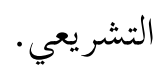

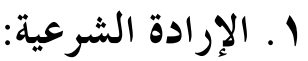

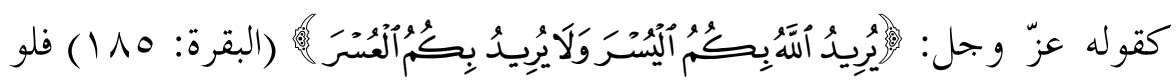

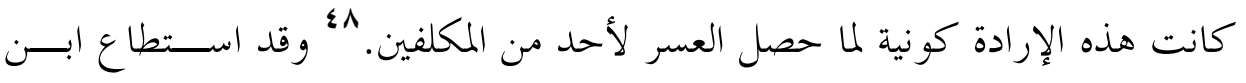

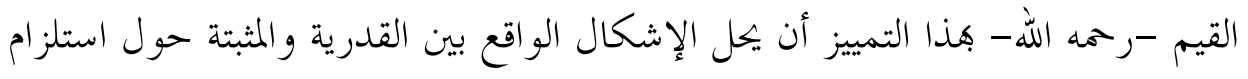
الأمر للإرادة، يقول في ذلك: "وبهذا التفصيل يزول الاشتباه في مسألة الأمسـر والإرادة

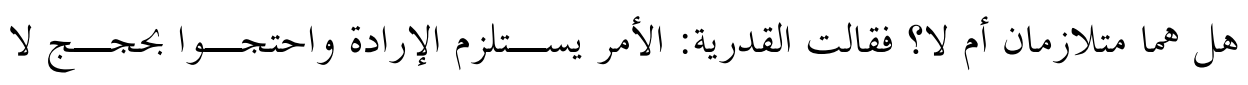

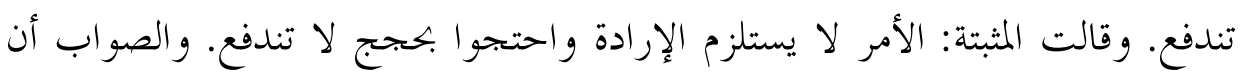

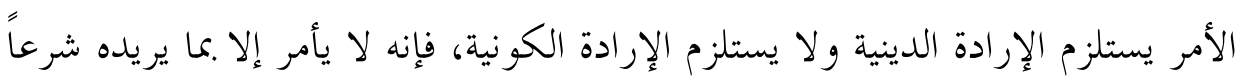

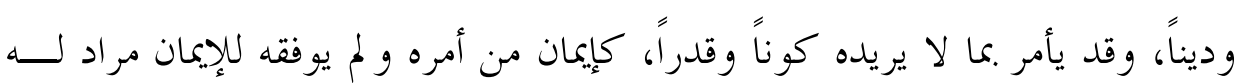

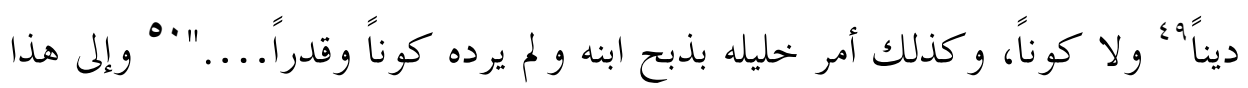

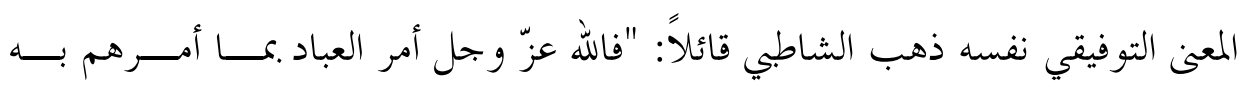

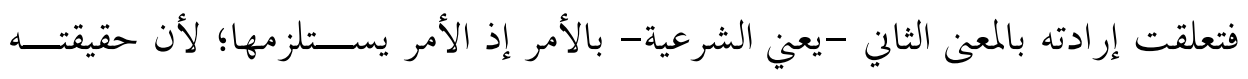

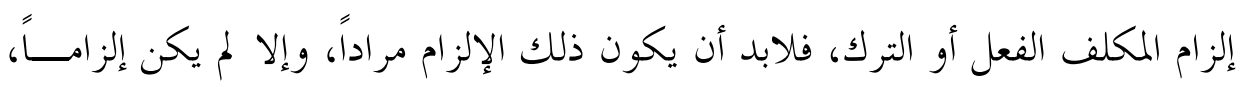

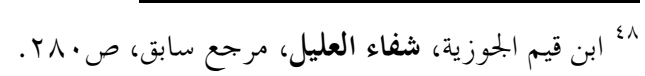

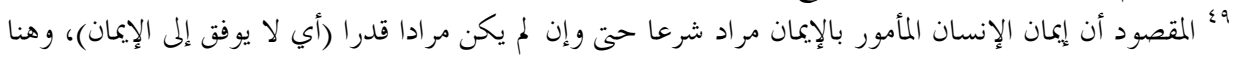

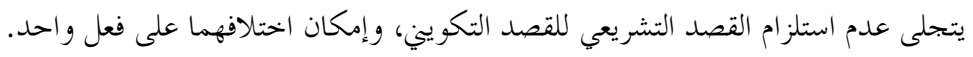

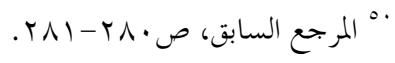




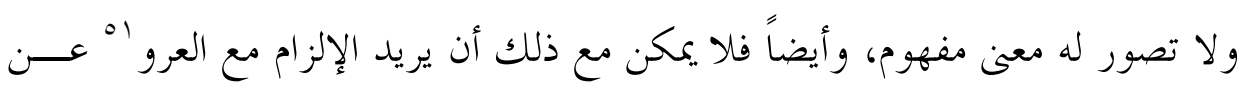

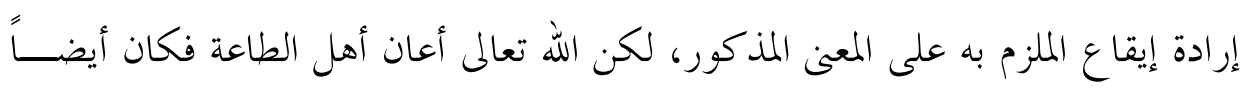

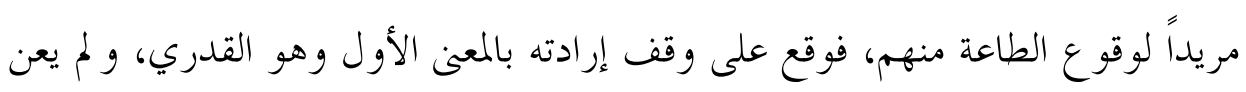
أهل المعصية فلم يرد وقوع الطاعة منهم فكان الو اقع الترك وهو مقتضى إرادته بالمعنى

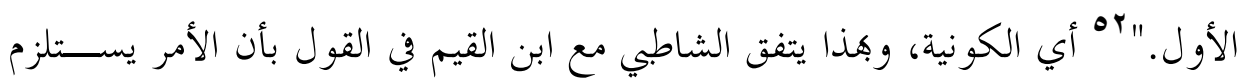

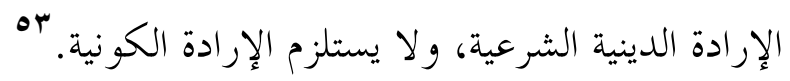

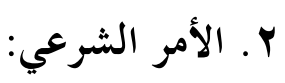

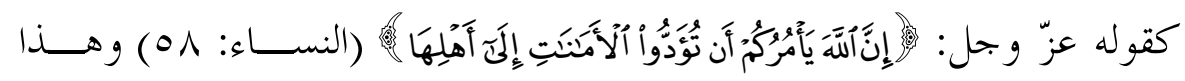

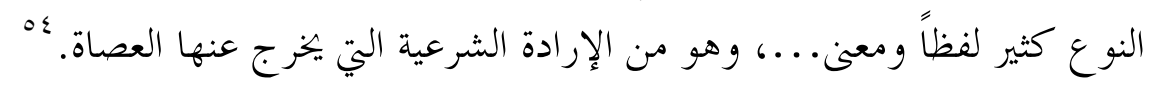

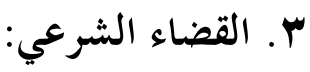

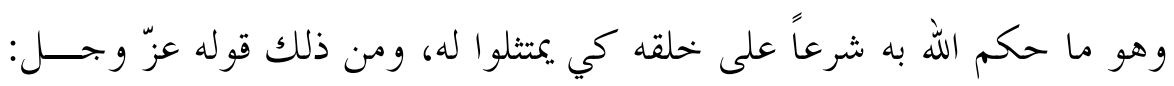

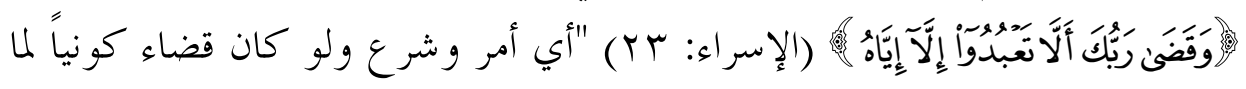
عبد غير الله. "هـ

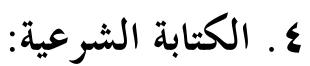

تم التعبير بلفظ "الكتابة" عن تشريع أحكام عديدة في القر آن الكريم، ففي إيجـــاب

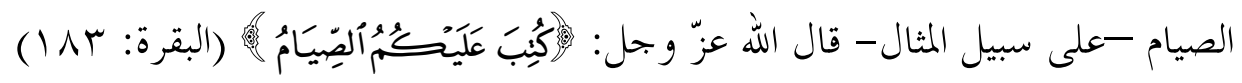

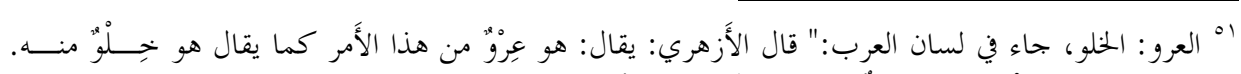

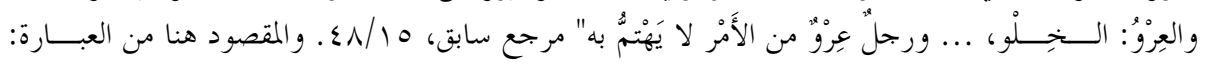

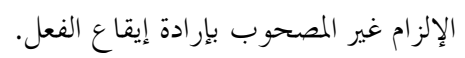

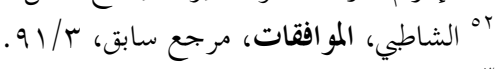

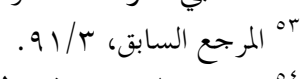

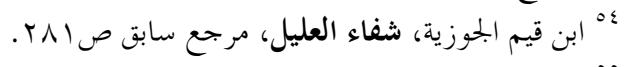

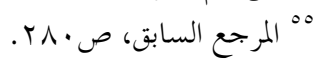




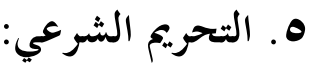

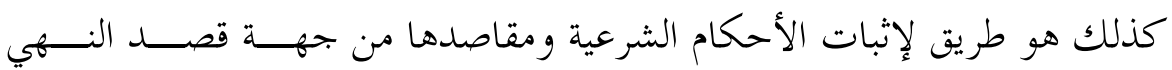

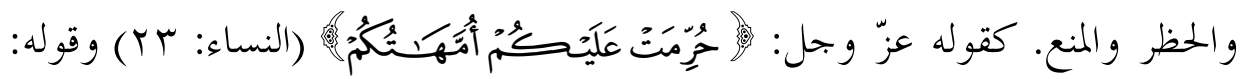

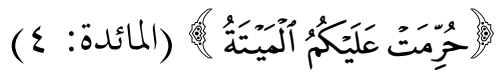

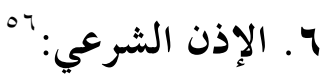

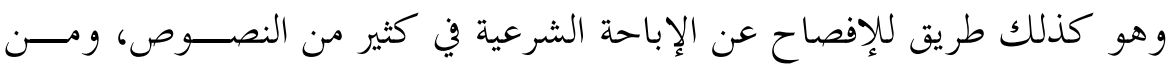

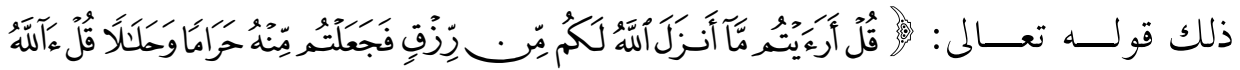

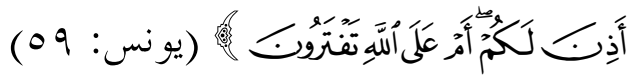

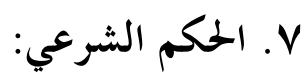

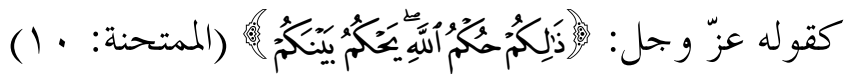

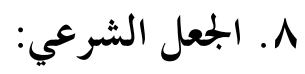

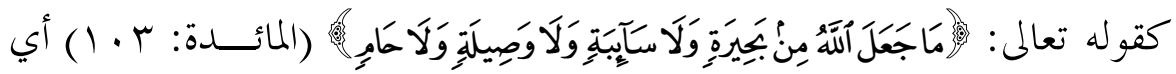

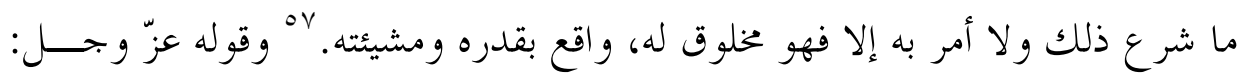

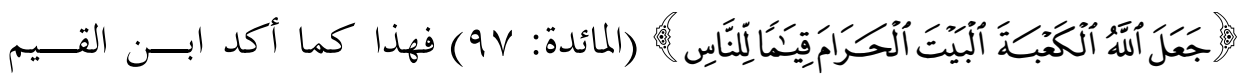

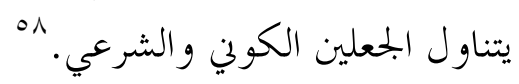

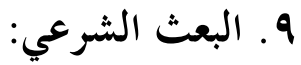

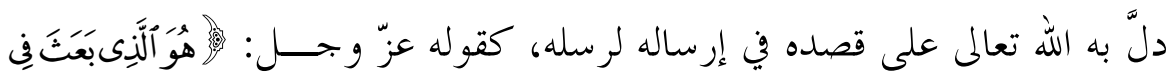

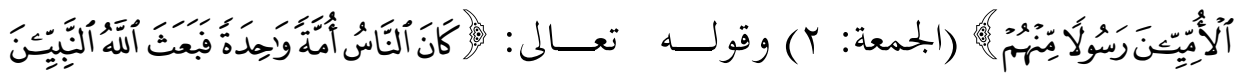

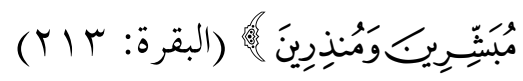

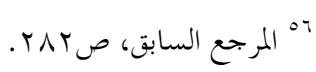

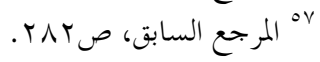

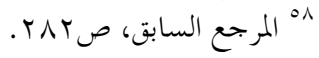




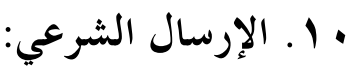

يقرب معناه من "البعث الشرعي" ذلك أنه استعمل في سياق الكلام عن القصــــ

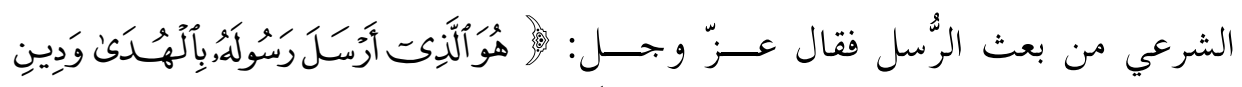

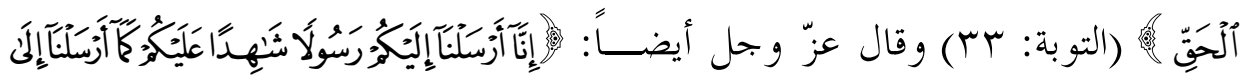

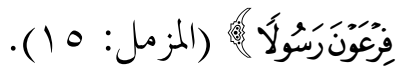

هذه بعض الأنواع التي تثبت أن الإرادة في القرآن الكريم وردت على ضـــبين،

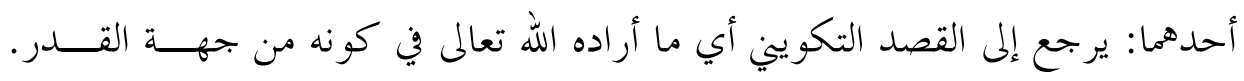

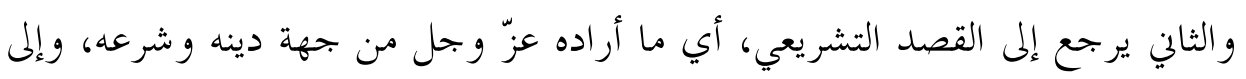
الضرب الثاني يستند الأصوليون في نسبة المقاصد إلى الشارع كما رأيناه عند الشاطبي.

\section{رابعاً: الفروق بين القصدين: التكويني والتشريعي}

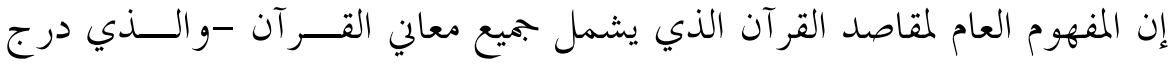

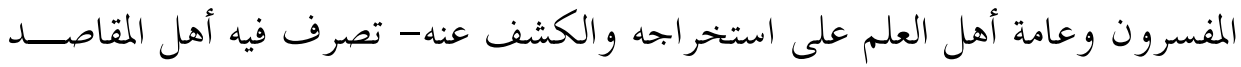

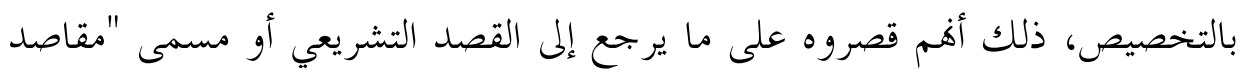

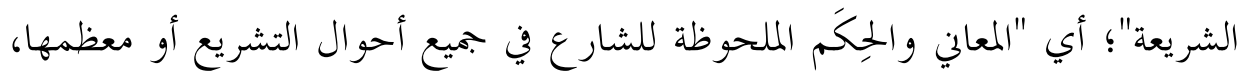

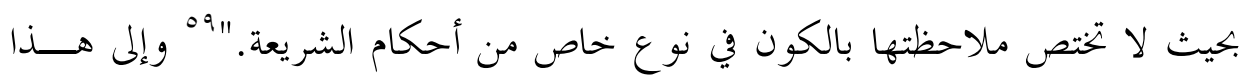

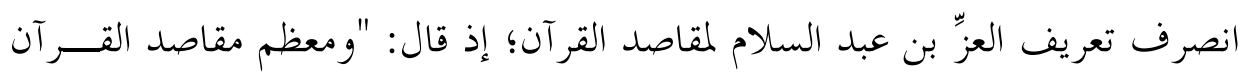

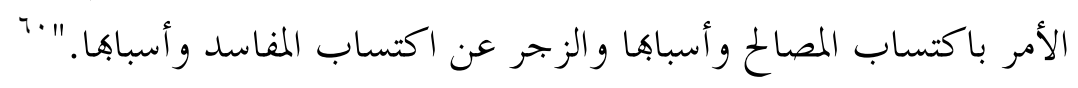

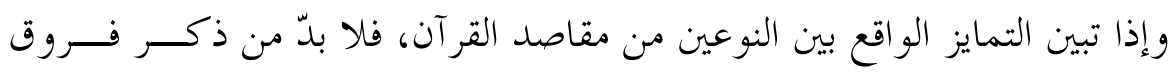

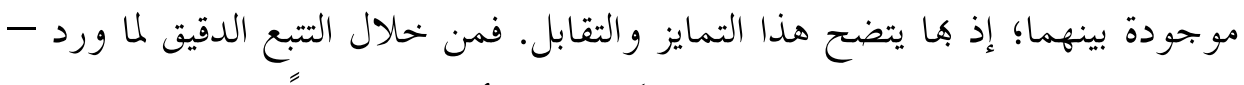

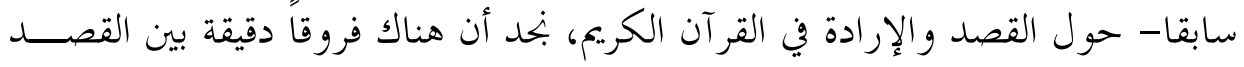
الكوني و القصد الشرعي، ومنها: 


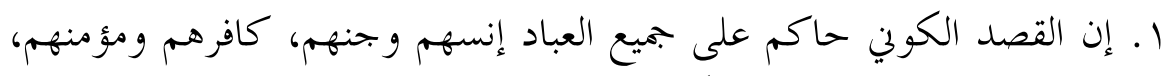

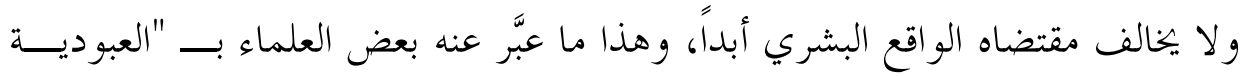

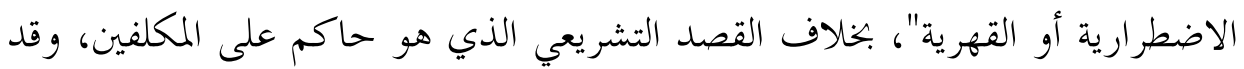

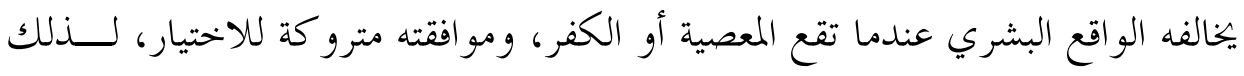

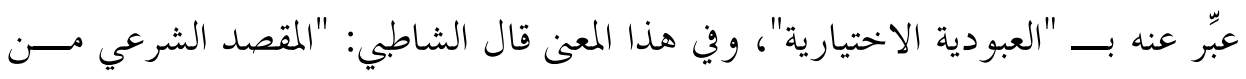

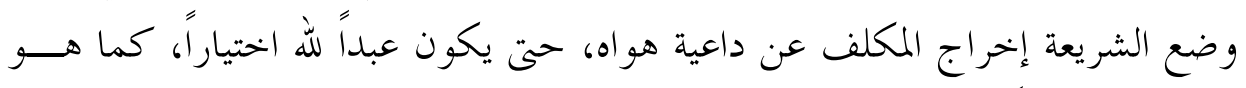

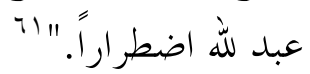

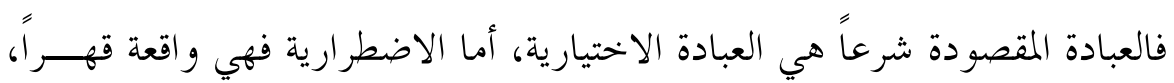

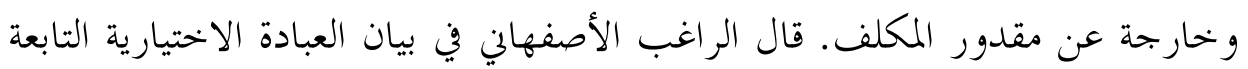

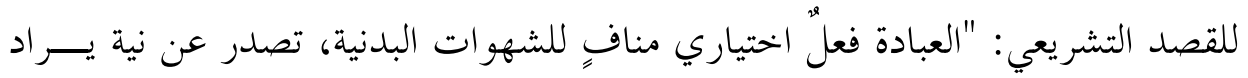

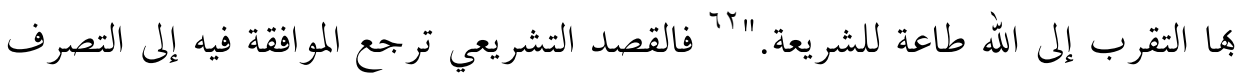

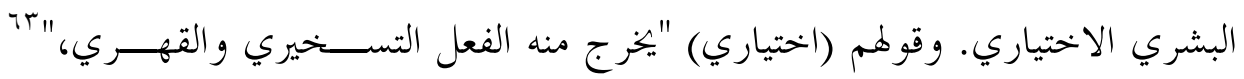

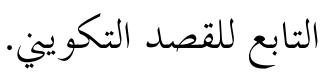

r. إن القصد التكويني لا يتعلق به تكليف في الغالب إلا مــن حيــث الإيمــان

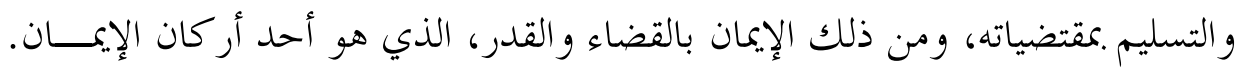

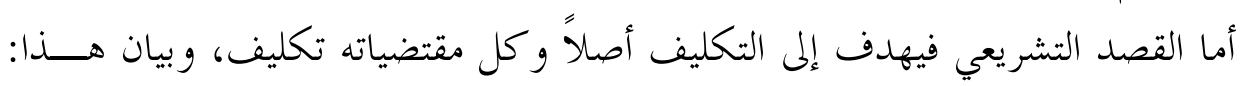

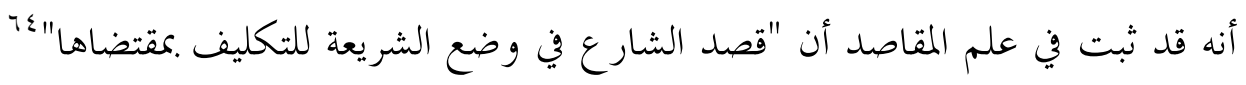

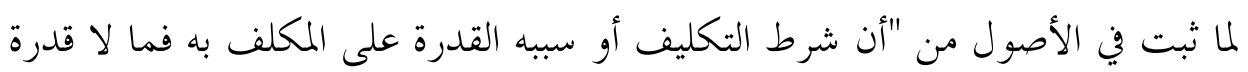

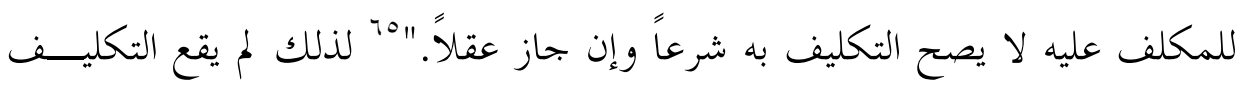

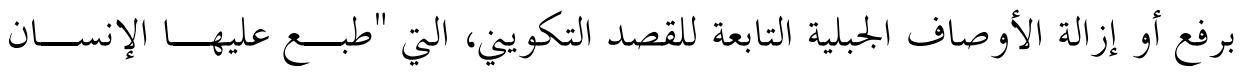

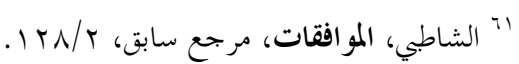

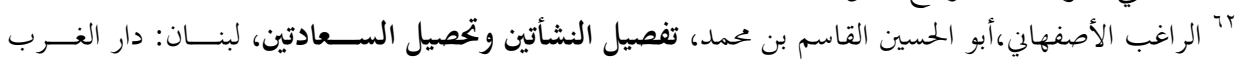

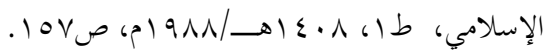

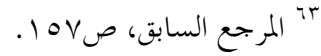

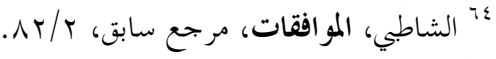

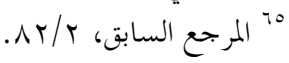




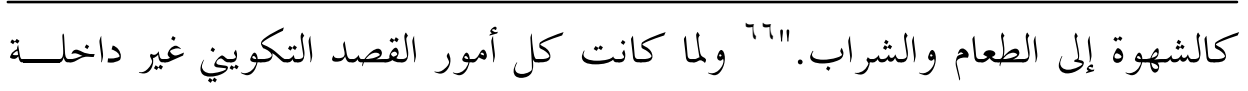
تحت اختيار ومقدور المكلف كان التكليف بها لا يصح.

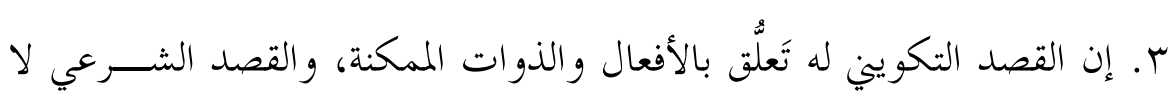

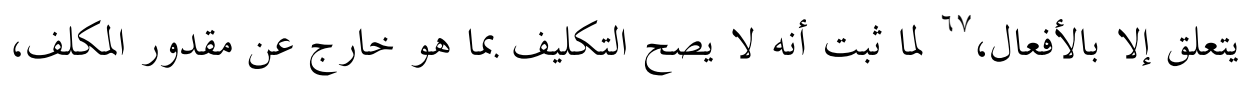

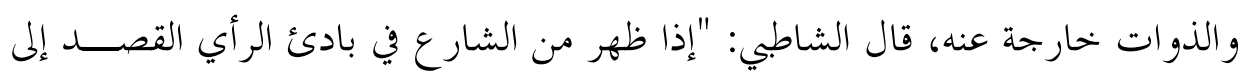
التكليف .ما لا يدخل تحت قدرة العبد، فذلك راجع في التحقيق إلى سوابقه أو لواحقه

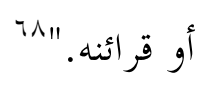

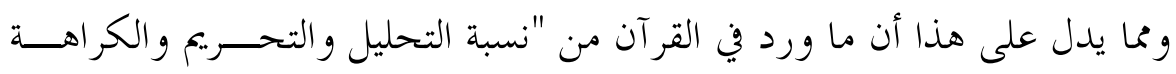

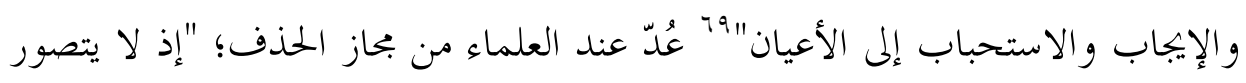

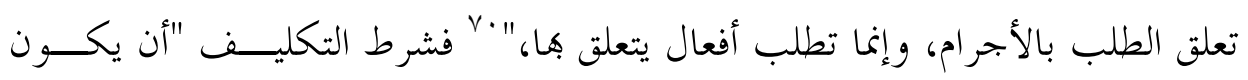

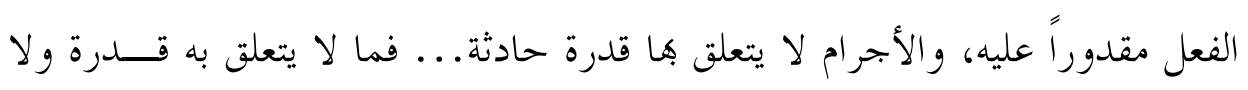

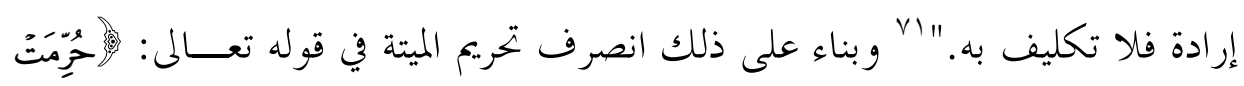

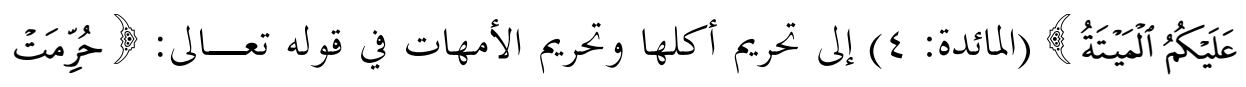

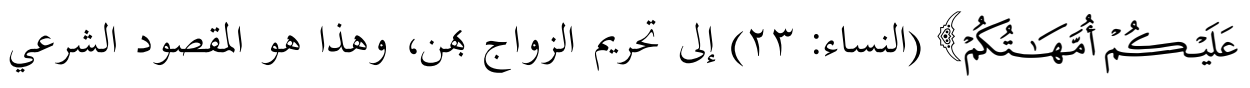
من ذلك..... n n

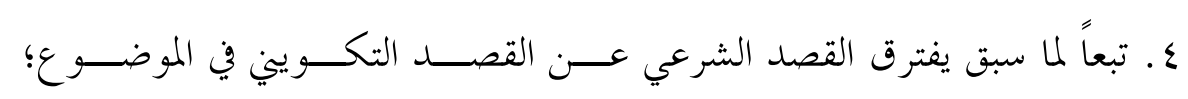

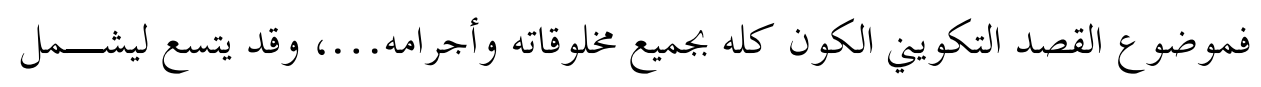

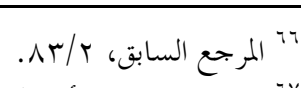

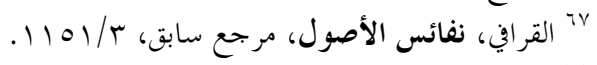

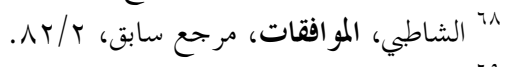

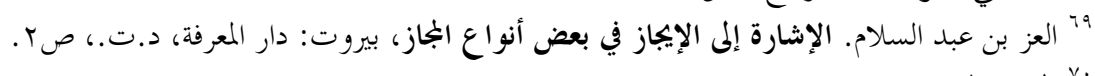

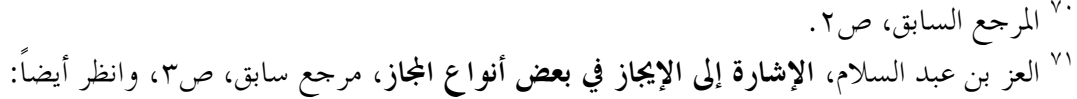

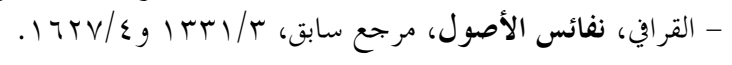


جميع الغيبيات التي استأثر الله بعلمها....، أما موضوع القصد التشريعي فهـــو أفتسال

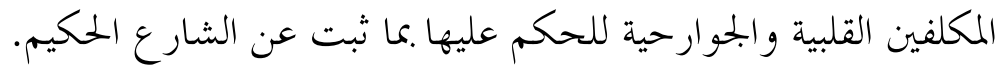

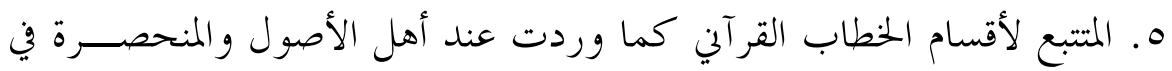

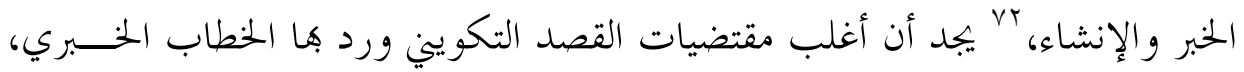
وأن أغلب مقتضيات القصد التشريعي ورد هـا الخطاب الإنشائي، ومما يدل على هذا:

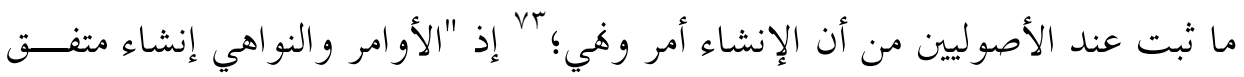

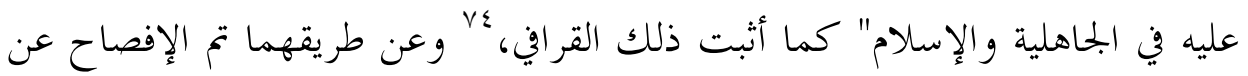

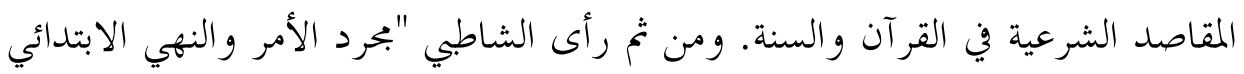

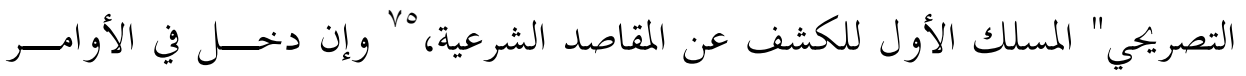

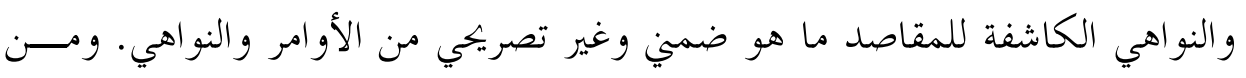

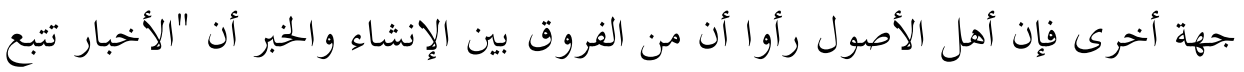

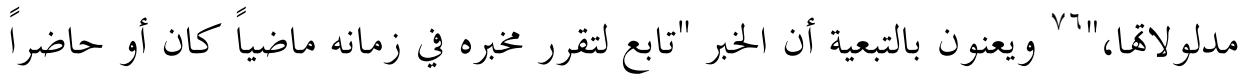

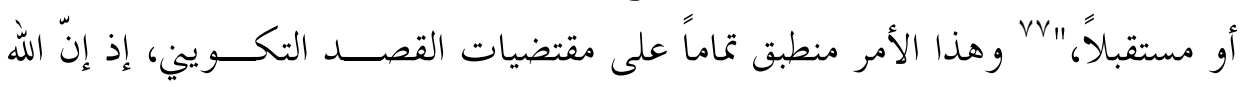
تعالى كثيرًا ما أخبر عن أقداره في خلقه عن الواقعة في الماضي والمتوقعة في المســتقبل.

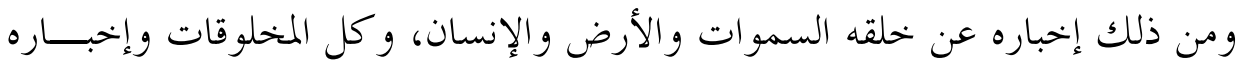

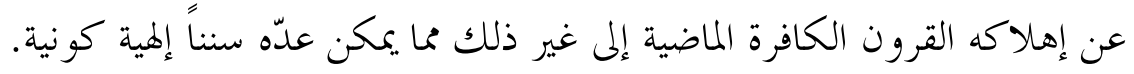

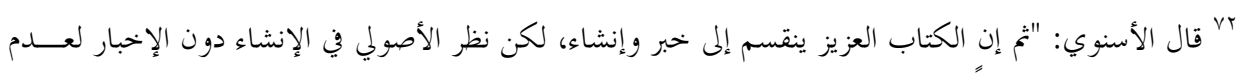

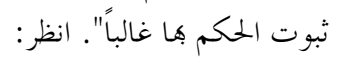

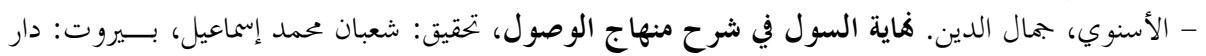

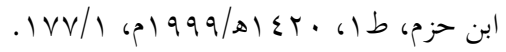

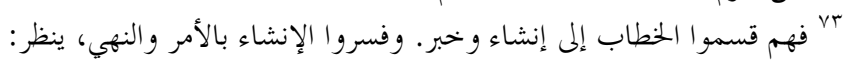

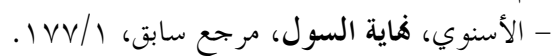

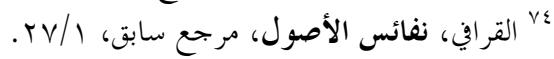

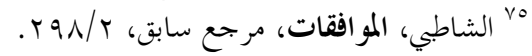

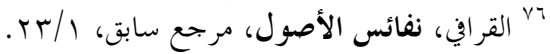
"rv 


\section{خامساً: الكشف عن القصد التشريعي من خلال الكرم بن النكوين والشريعي التصد التكويني}

يُعدّ القصد التكويني مسلكاً من مسالك الكشف عن المقاصد الشـــرعية، وعلــى

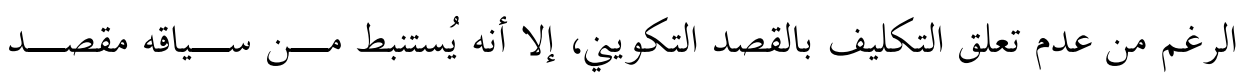

$$
\text { شرعي وذلك لوجوه هي: }
$$

الوجه الأول: مفاده أن ورود الإخبار بالقصد التكويني في القرآن الكــــيم لــيس مقصوداً لذاته، وإنما لأجل تثبيت أمور تكليفية منها: توحيد الله تعالى، و الإيمان بأقداره

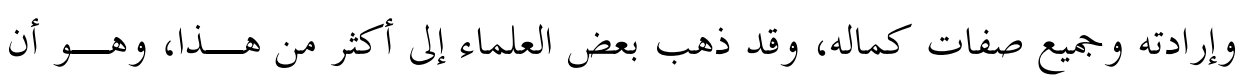

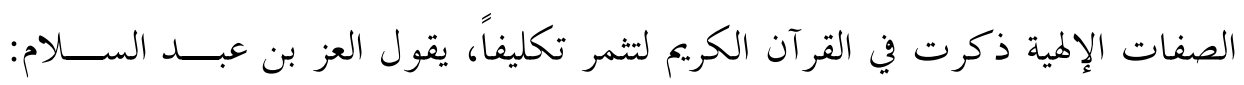
"أخحاق القرآن ضربان: أحدها التخلق بخصائص العبودية كالذل والإذعان، والثـــاني

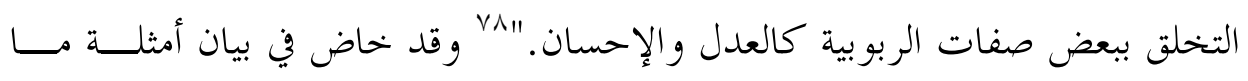

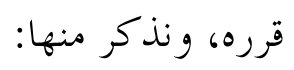

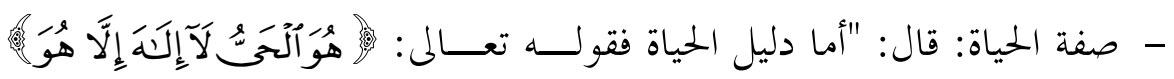

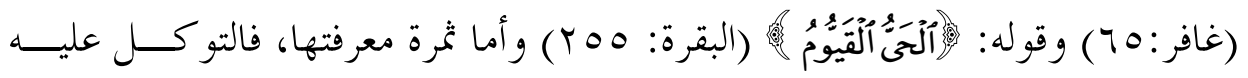
و الالتجاء إليه.

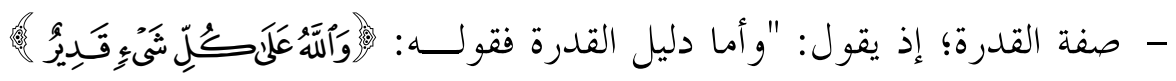

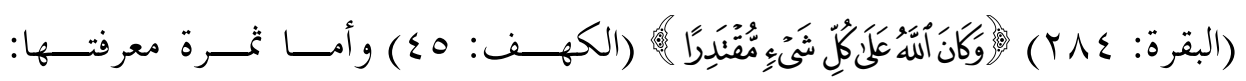
فالإجلال، والمهابة ورجاء الإنعام، وخوف الانتقام لشمول قدرته لأنواع ما نفع وضر $\Lambda$. و ساء و سر

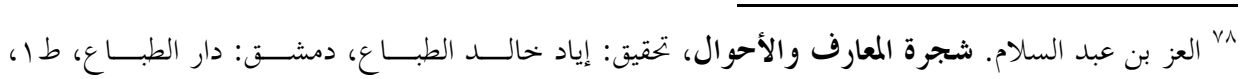
. ra • لمرجع السابق، صر السابق، صبr. 


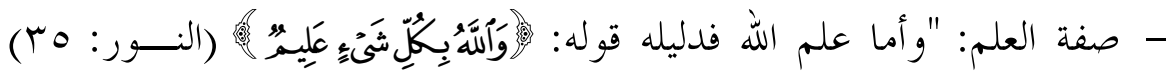

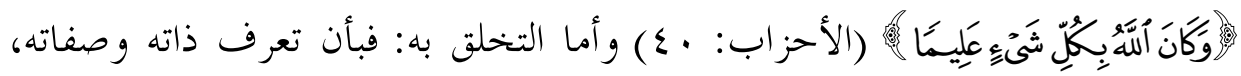

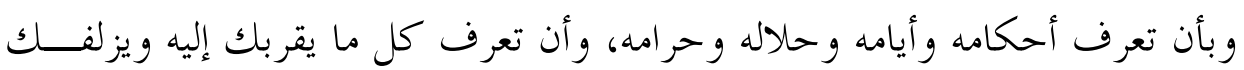

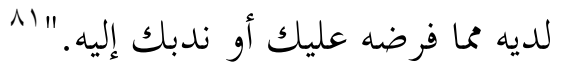

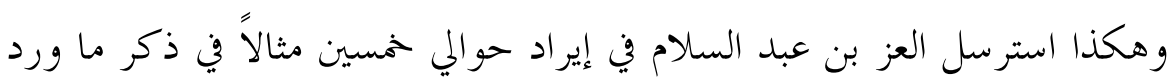

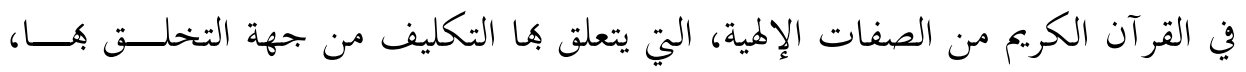
فضلاً عن جهة الإيمان بها.

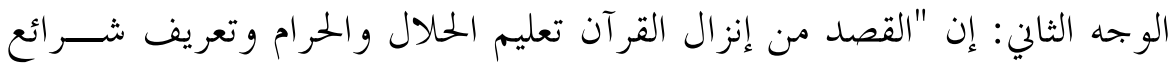

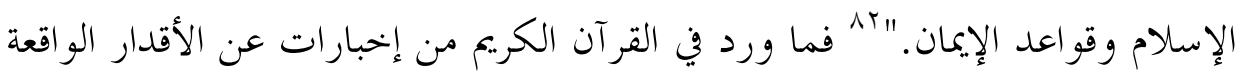

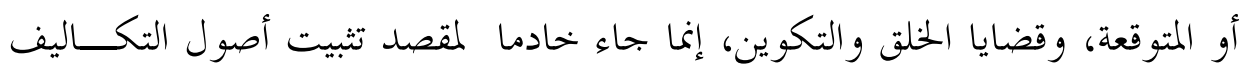

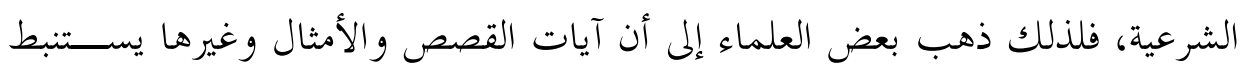

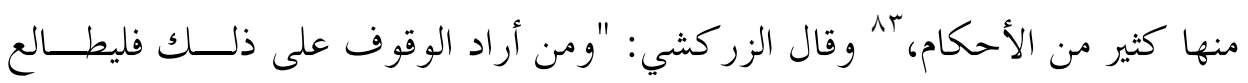

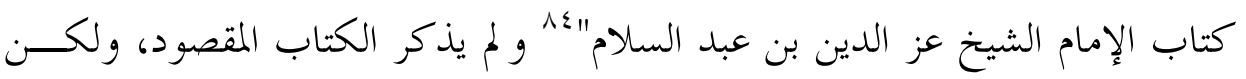

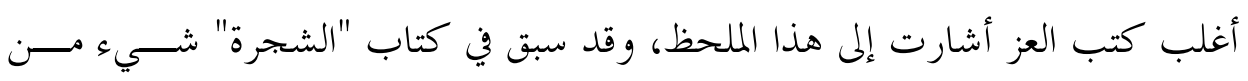

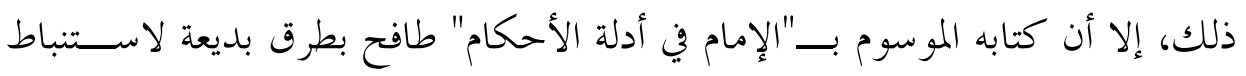

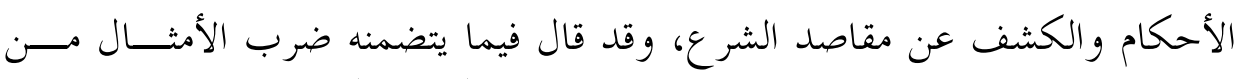

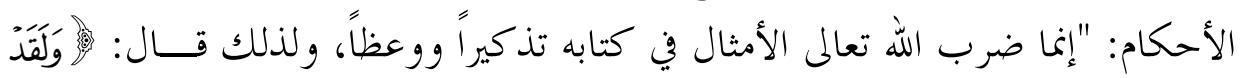

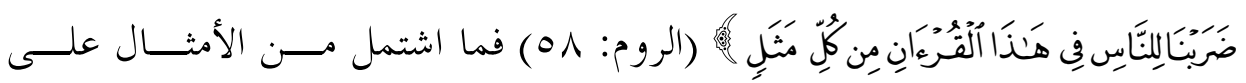

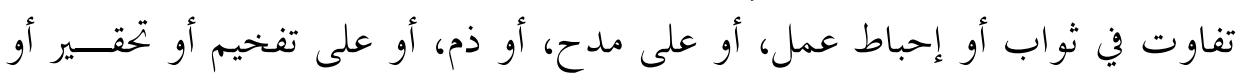

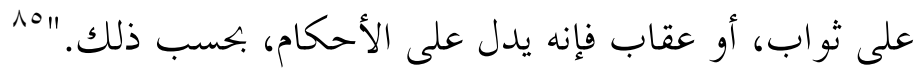

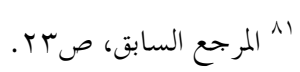

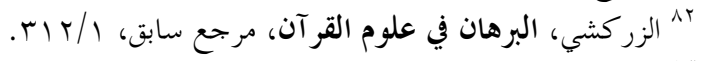

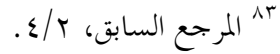

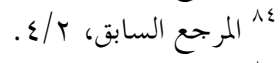

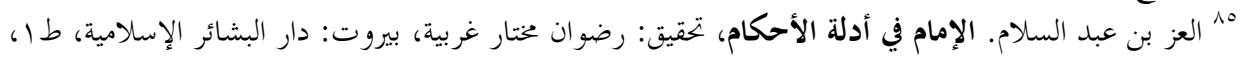


ومن هنا ينتفي ذلك الحصر الذي ذهب إليه بعض العلماء لآيــات الأحكـــام في

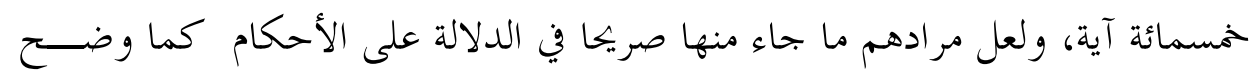
ذلك الزركشي في البرهان.

الوجه الثالث: يتلخص في تجارب العلمـــاء في اســتنباط الأحككــام الشـــرعية و مقاصدها، باعتبار الآيات الواردة في سياق الإفصاح عن القصد التكويني، ومن ذلك:

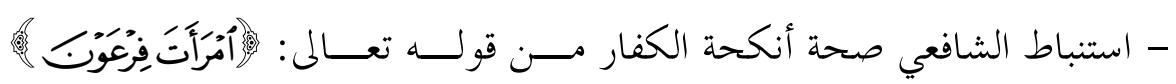

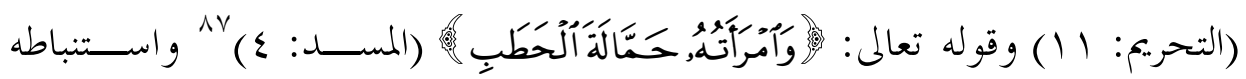

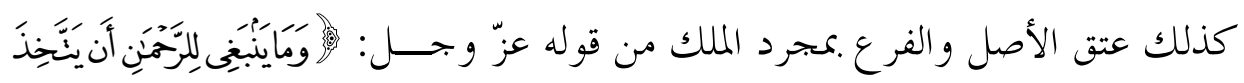

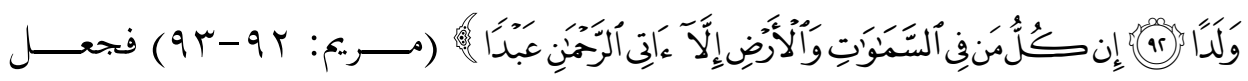
العبودية منافية للو لادة حيث ذكرت في مقابلتها، فدل على أهما لا يجتمعان، ^^و والآية سيقت لغير ذلك.

- و استنباط علي وابن عباس رضي الله عنهما أن أقل الحمل ستة أشهر من قولــهـ

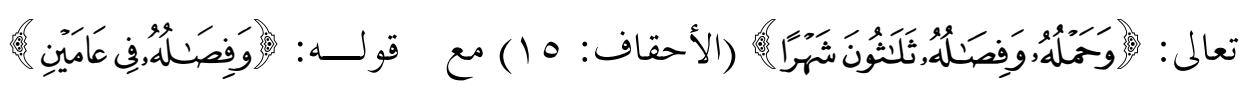
^و (لقمان: 1 ( )

- ومن هذا الوجه كذلك استفادة العلماء الإباحة من امتنان الله تعالى .ما في

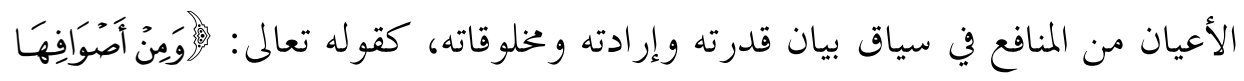

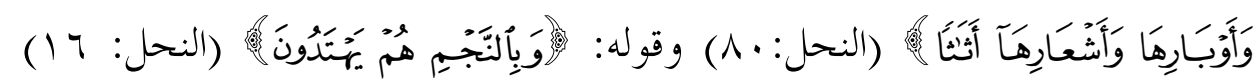

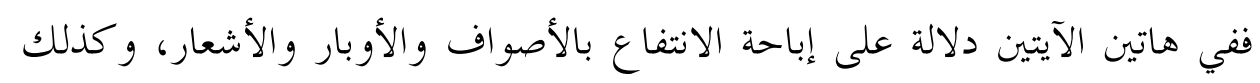
إباحة الاهتداء بالنجوم.

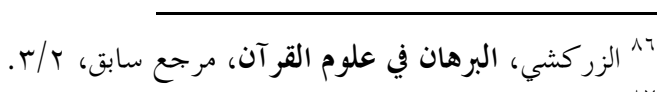

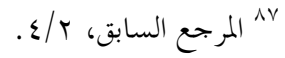

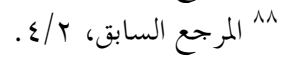

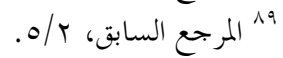

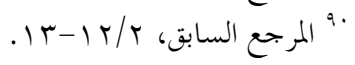




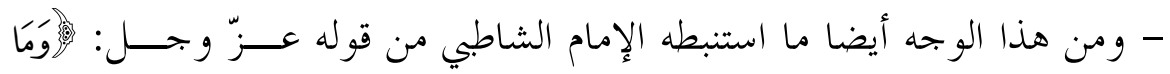

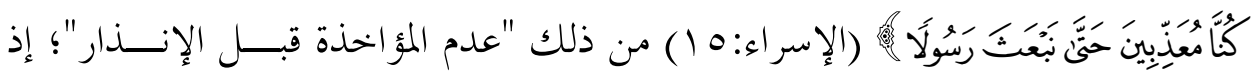

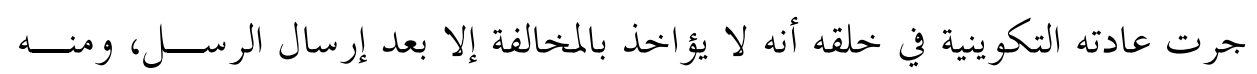
الإبلاغ في إقامة الحجة.

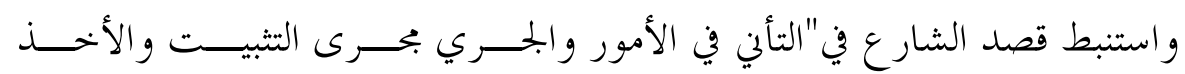

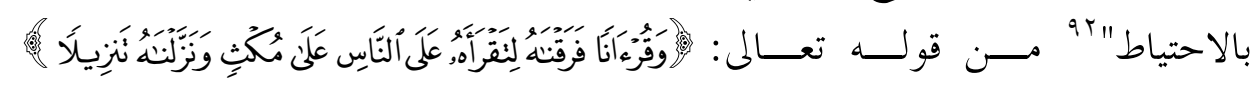

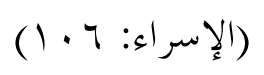

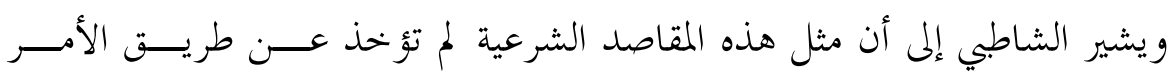

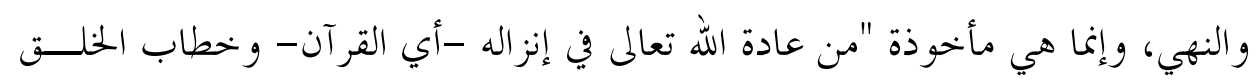

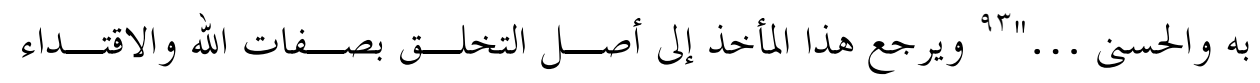
بأفعاله، ع9 وهذا يشبه ما ذكره العز سابقاً.

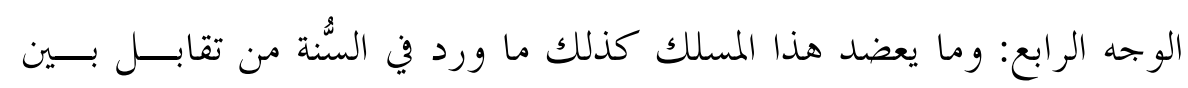

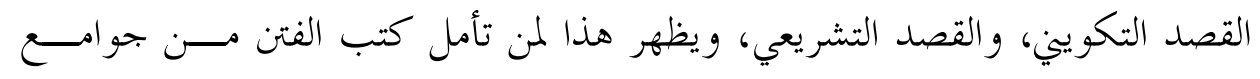

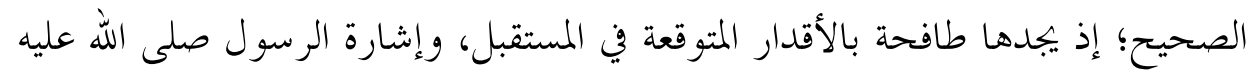

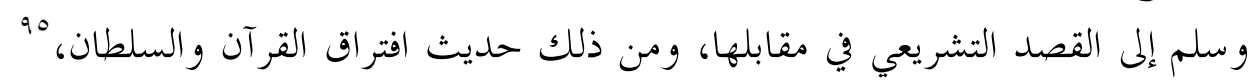

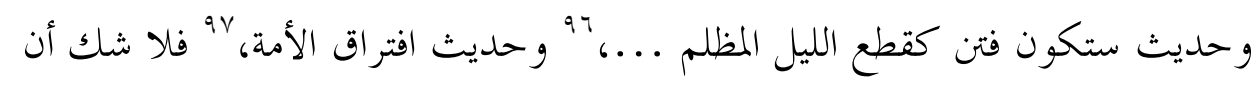

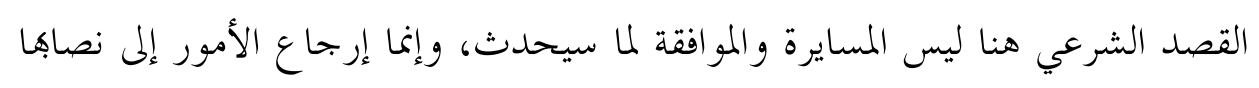

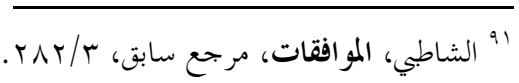

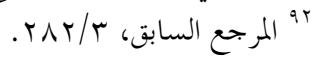

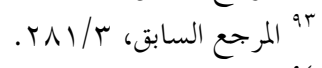

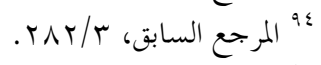

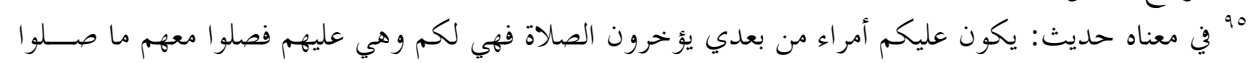

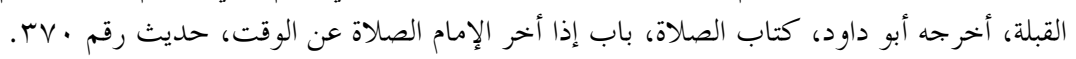

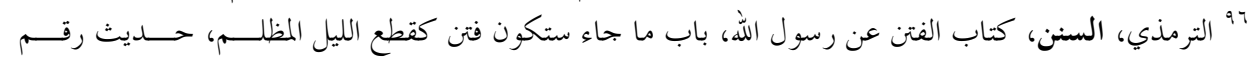


بالدوران مع القرآن حيث دار، ومحاربة الفتن والحفاظ على وحدة الأمة، وهذا الوجه يحتاج إلى بحث وليس هذا مقامه الهر.

وهكذا تتبين صحة هذا المسلك، ومن هنا لا يصح الاحتجــــاج علــى إســقاط التكاليف بالقصد التكويني، كما فعل الكفار عندما أمرهم الله تعالى بالإنفاق فقـــالوا:

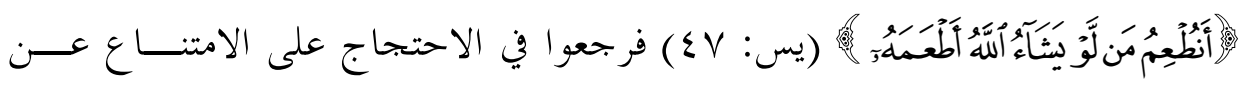

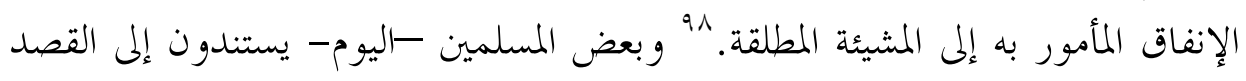

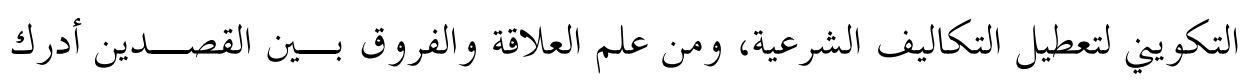
الخطأ الواقع في هذا الباب.

أدركنا فيما سبق أن الحمديث عن مقاصد القرآن راجع إلى الحديث عــنـ الإرادة،

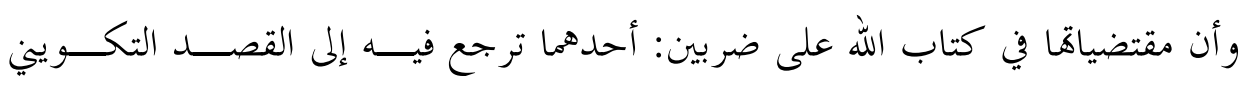
و الآخر ترجع فيه إلى القصد التشريعي.

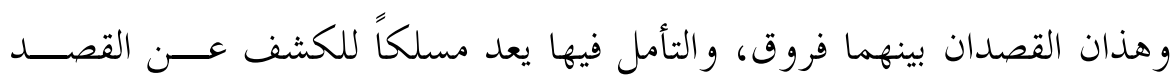

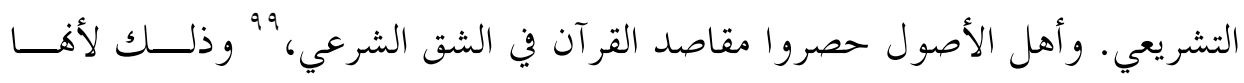

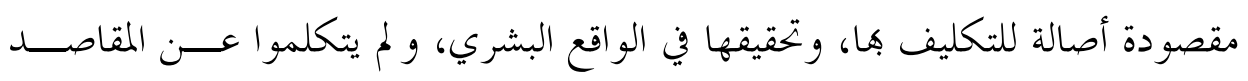
التكوينية إلا في النادر وبصورة عرضية.

\section{سادساً: بعض المقتضيات الدلالية للمقاصد القر آنية}

إن الدلالية المقاصدية للقر آن الكريم -بوصفه خطاب الله تعالى إلى البشر - ترســـم

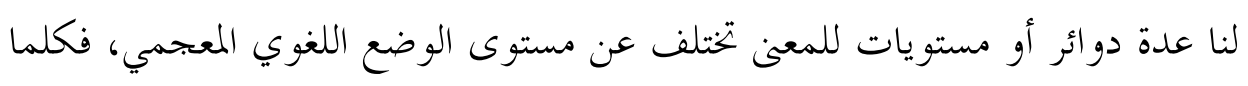

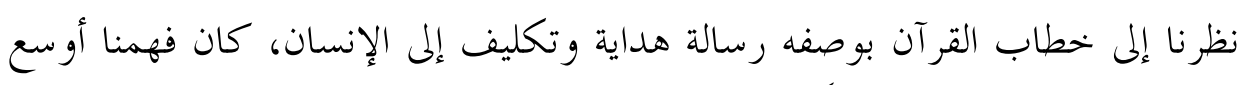

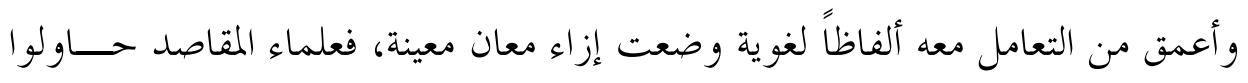

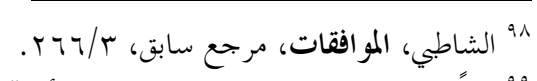

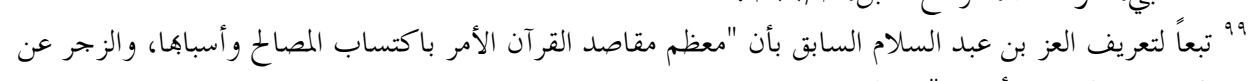

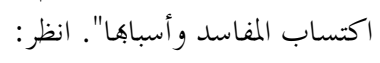
- العز بن عبد السلام، قواعد الأحكام، مرجع سابق، صو ص. 


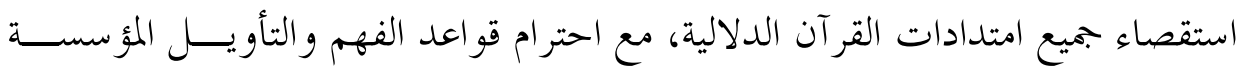

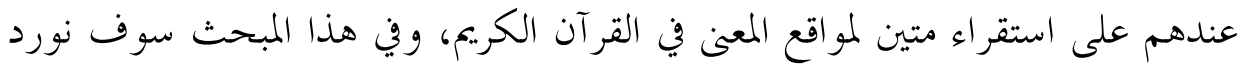

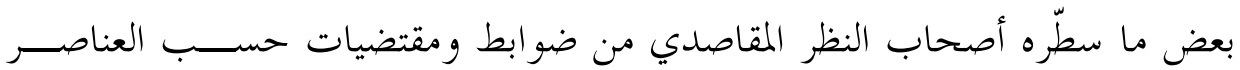

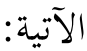

\section{1 ـ ـ مقاصد القر آن الكريم من المنظوم إلى المعقول:}

قرر علماء الأصول أن لفظ الخطاب الشرعي له ثلاثة امتـــدادات عــبروا عنــهـا

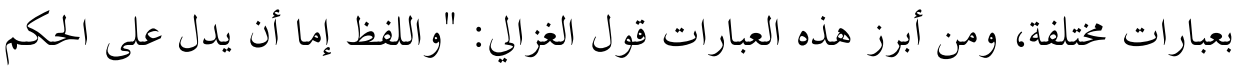

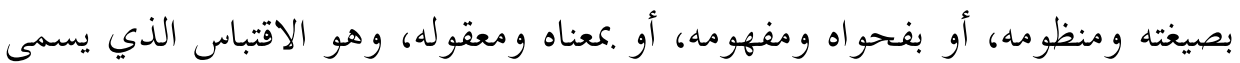

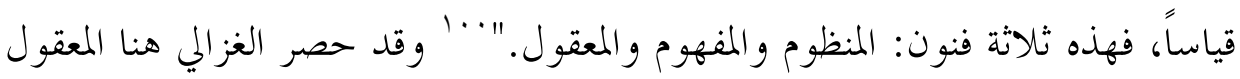

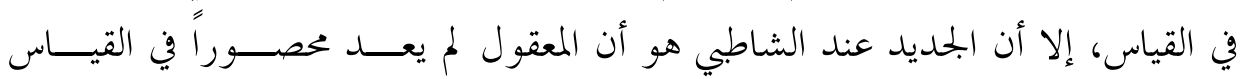

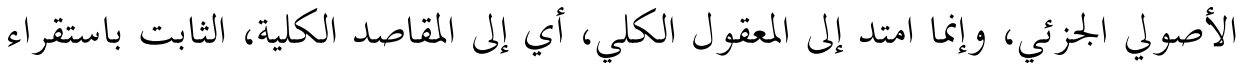

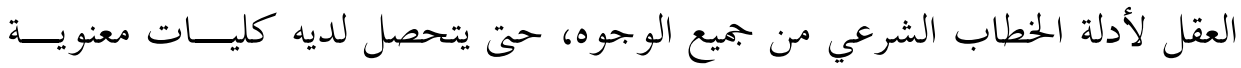

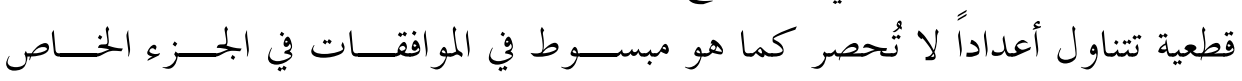
بالمقاصد، في سياق بيان طريقة استدلاله على القواعد الثلاث: الضروريات والحاجيات و التحسينيات.

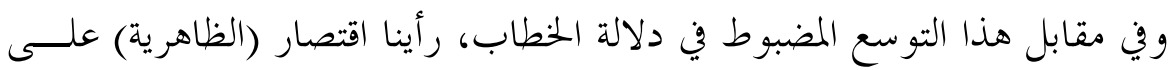

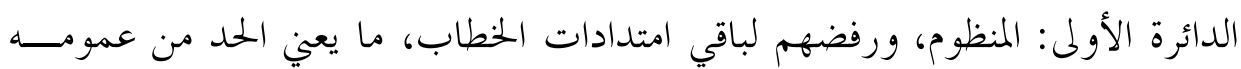

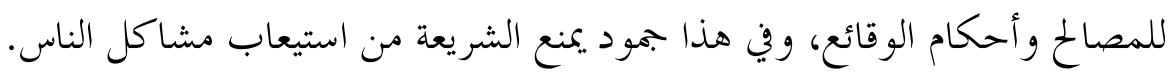
r ـ مقاصد القر آن الكريم بين المستوى الأصلي والمستوى التبعي:

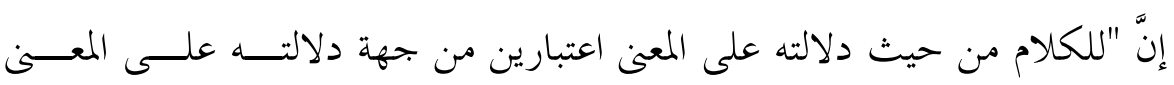

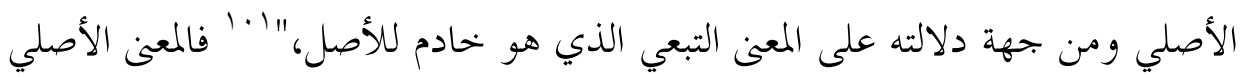
”. الغزالي، أبو حامد. المستصفى، طبعه وصححه محمد بن عبد السلام عبد الشافي، بيروت: دار الكتب العلمية،

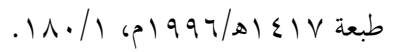

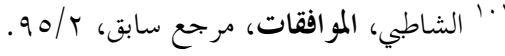


هو ما جاء الخطاب مسوقاً إليه أصالة، و بالقصد الأول، و كأن الكلام ما كان لِيَرِد إلا

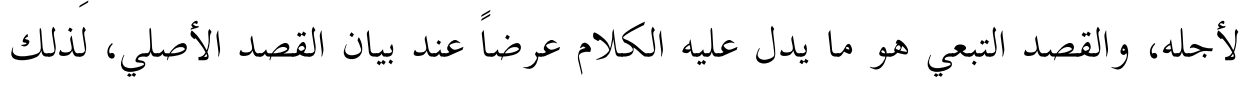
فهو لم يذكر هنا إلا من جهة تبعيته و خدمته للمعنى الأصلي. وقد تساءل أهل المقاصد عن الوجه الذي تستفاد منه الأحكام، وهل يختص بجهة

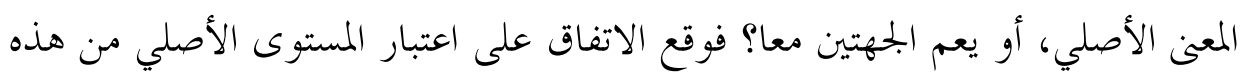

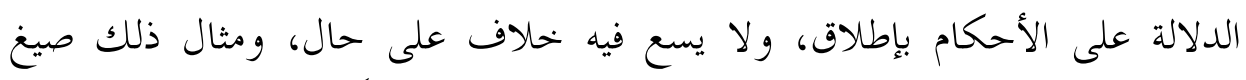
الأوامر و النواهي والعموم و الخصوص، وما أشبه ذلك، بجرداً من القرائن الصارفة لها فيها

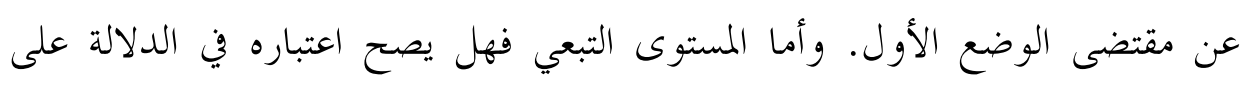
الأحكام من حيث تفهم منها معان زائدة على المستوى الأصلي أم لا؟ وهذا محل تردد

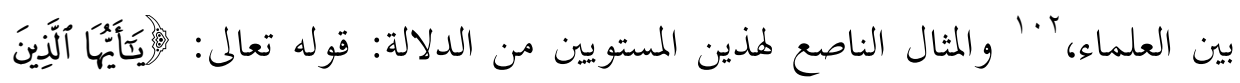

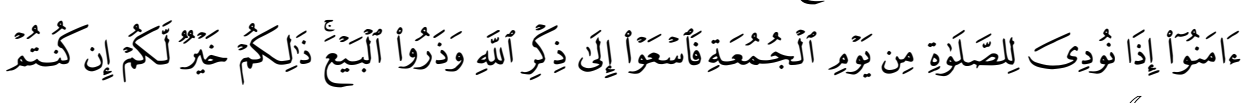

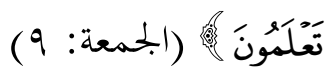

فقوله: "فاسْعَوا إلى ذكُر الله" مقصودة الحفظ على إقامة الجمعة وعدم التفـــريط

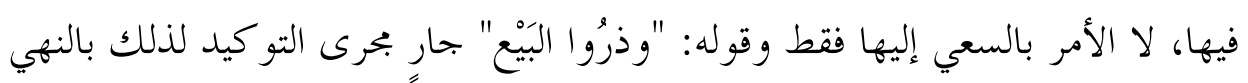

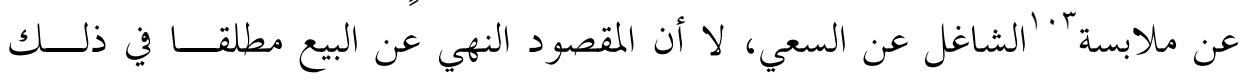

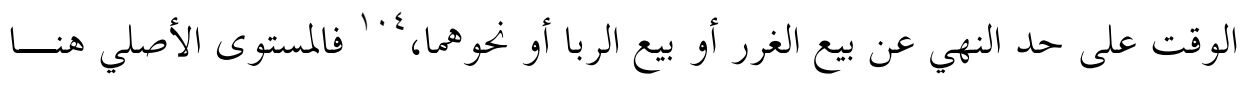

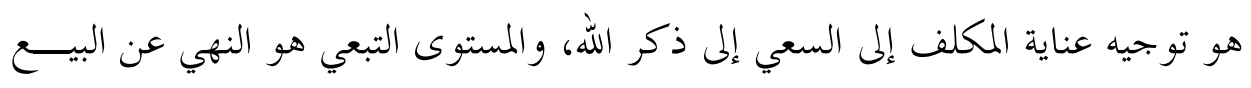
عند النداء و بعده، حتى يتم الانصر اف من الفيه الصلاة.

وعلى هذا توجه أهل المقاصد إلى التركيز على المستوى الأصلي من الدلالة، لذلك

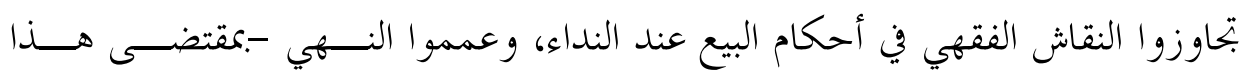

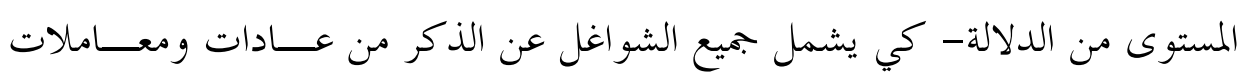

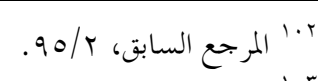

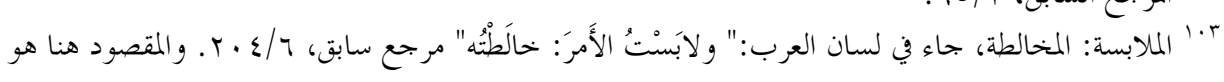

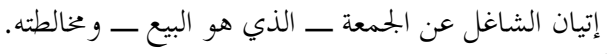

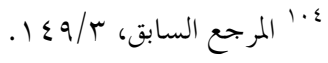


وحتى عبادات تتعارض مع فريضة الوقت، هُ1 قال الغزالي في شفاء الغليل: "...إن هذه الآية في سورة الجمعة إنما نزلت وسيقت لمقصد وهو بيان الجمعةد... وما نزلت الآيــة

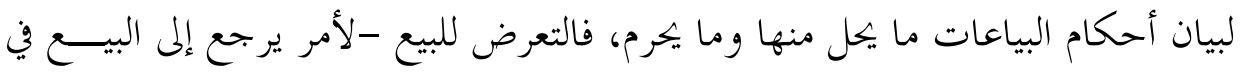

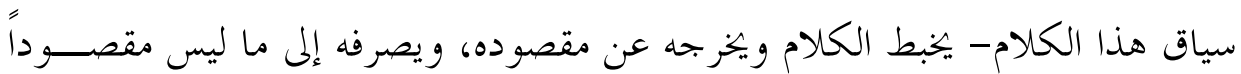
به، وإنما يحسن التعرض للبيع إذا كان متعلقاً بالمقصود، وليس يتعلق به إلا من حيــــثـ

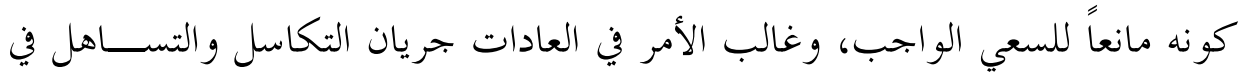
السعي بسبب البيع، فإن وقت الجممعة يو افي الخلق وهم منغمسون في المعاملات. فكان

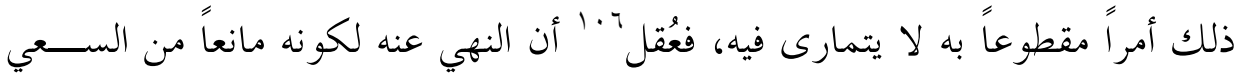

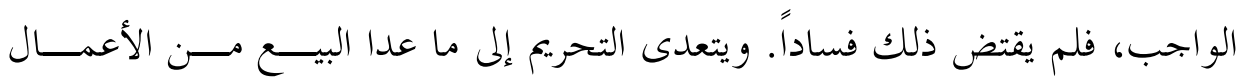

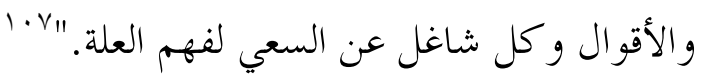

\section{ب. مقاصد القر آن الكريم بين الدلالة الوضعية والدلالة الاستعمالية:}

يقسم عموم دلالة الألفاظ بحسب الوضع و الاستعمال إلى نوعين:

النوع الأول: العموم الوضعي وهو قياسي، وهو بتعبير الشاطبي "ما تـــل عليـــهـ

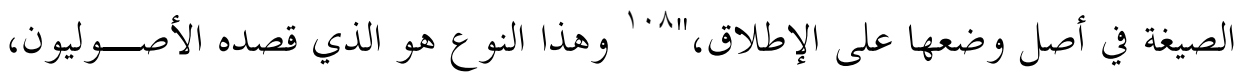
فلذلك يقع التخصيص عندهم بالعقل والحس و سائر المخصصات المنفصلة.

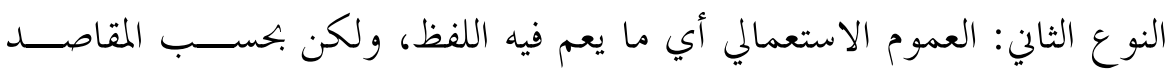

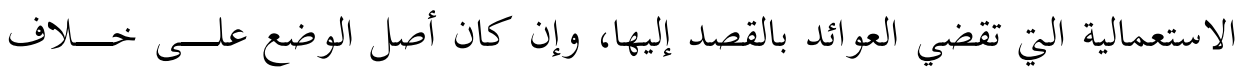
ذلك.

وقد ذهب الشاطبي إلى أن الدلالة المقصودة في حالة التعارض بين هذين النـــوعين

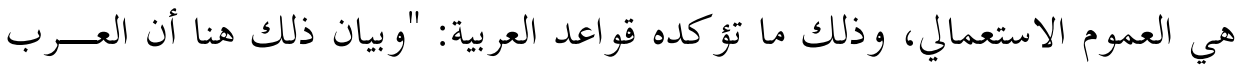
1.0 1 كتحية المسجد عند بعضهم.

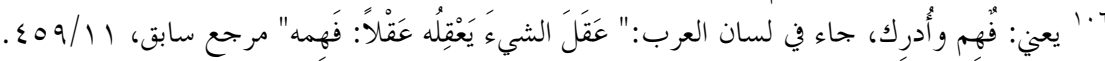

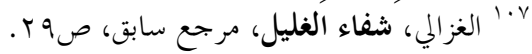

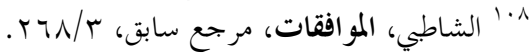

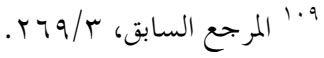


تطلق ألفاظ العموم بحسب ما قصدت تعميمه مما يدل عليه معنى الكلام خاصــة، دون

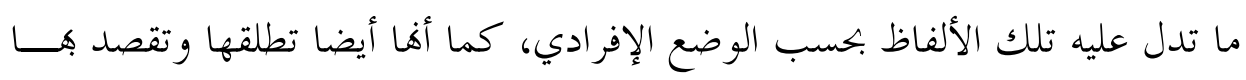
تعميم ما تدل عليه في أصل الوضع، و كل ذلك مما يدل عليه مقتضى الحال." ل"

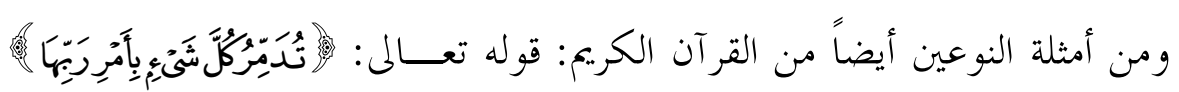

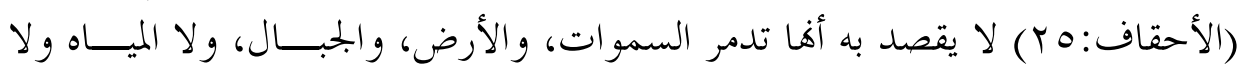
غيرها مما هو في معناها، وإنما المقصود تدمر كل شيء مرت عليه مما شأها أن تؤثر فيه

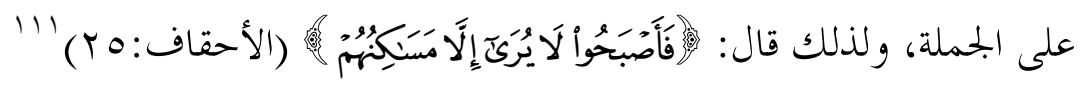

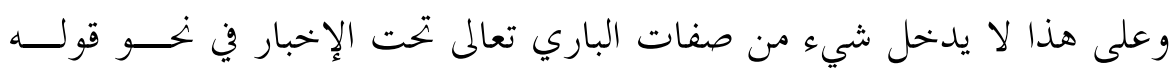

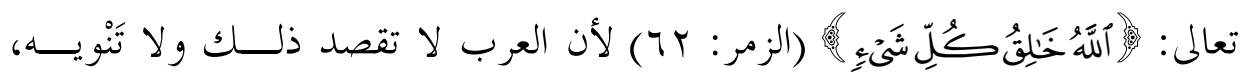

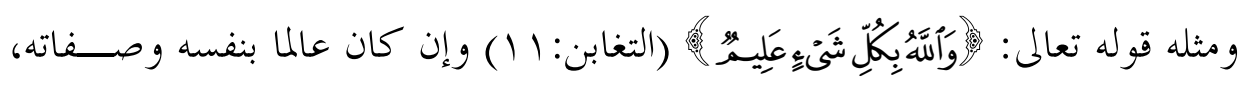
ولكنّ الإخبار إنما وقع عن جميع ما سواه.

ومن الدليل على هذا أنه لا يصح استثناء هذه الأشياء بحسب اللسان، فلا يقـــال

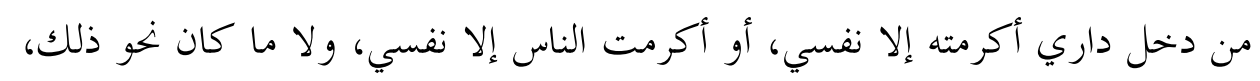

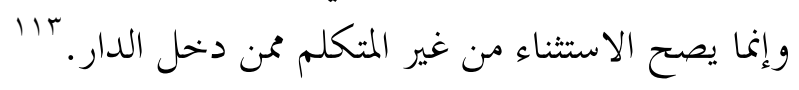
ومن أمثلته أيضاً ما أخرجهه البخاري عَنْ عَبْدِ اللَّهِ رَضِيَ اللَّهُ عَنْهُ قَالَ: "لَمَّا نَزَكَتْ

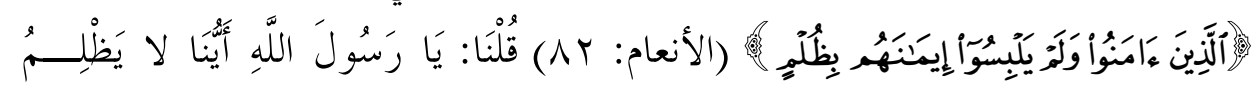

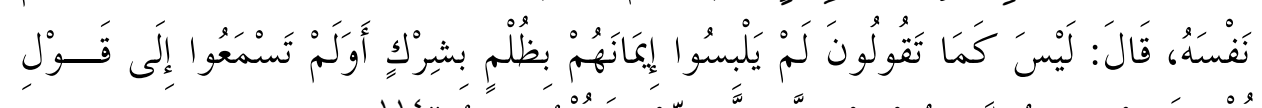

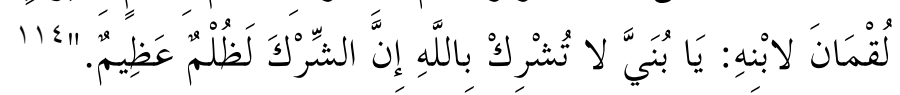

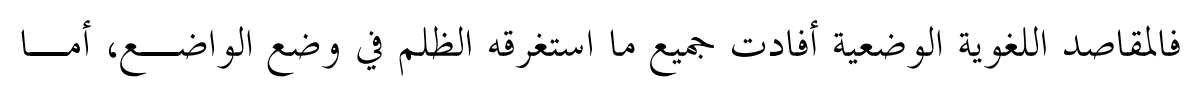
المقاصد القر آنية فقد أفادت أن المقصود من الظلم هنا هو الشرك اكبالله.

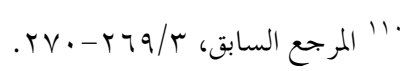

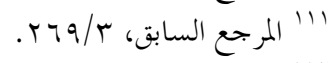

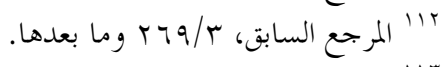

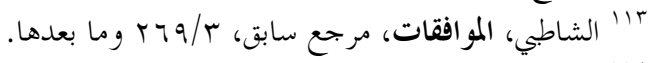

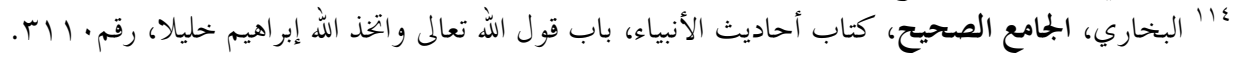




\section{ع ـ مقاصد القرآن الكريم بين العموم اللفظي والعموم المعنوي:}

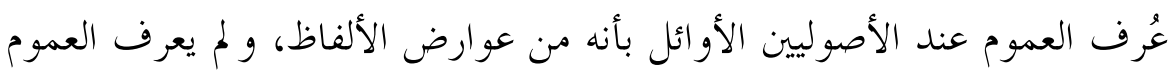

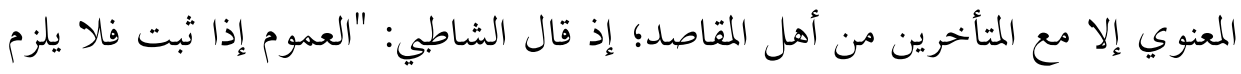

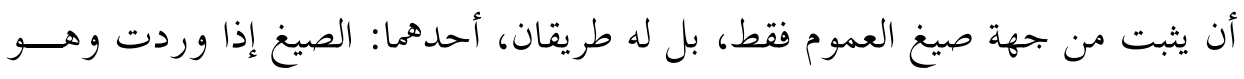

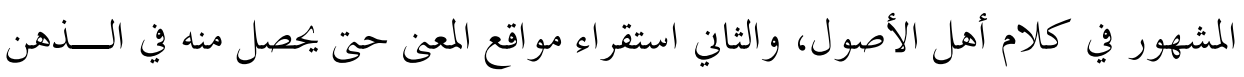
أمر كلي عام، فيجرى في الحكم بحرى العموم المستفاد من الصيغ."

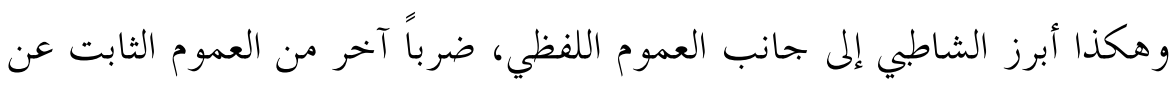

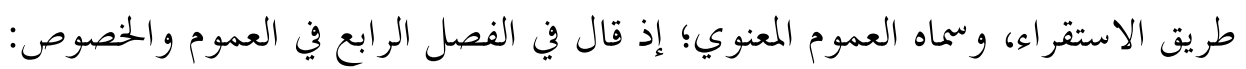

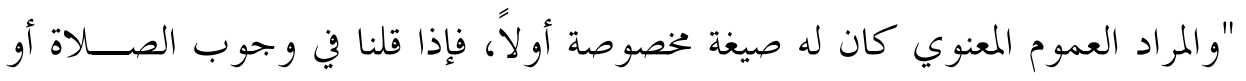

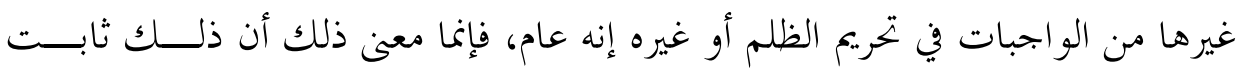

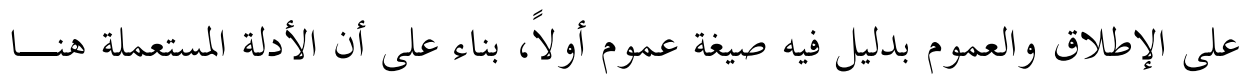

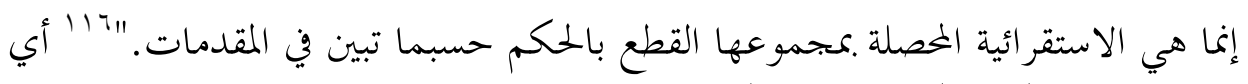

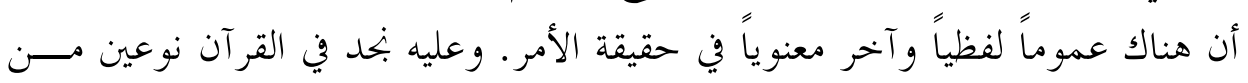

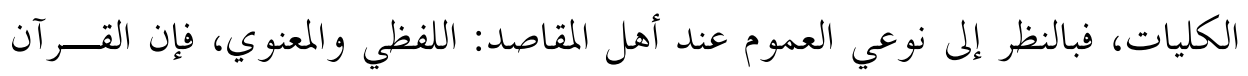
تضمن الكليات اللفظية كما تضمن الكليات المعنوية:

النوع الأول: الكليات اللفظية وهي كثيرة في القرآن الكريم، ومنها قوله تعسالى:

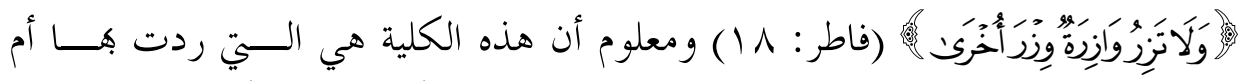

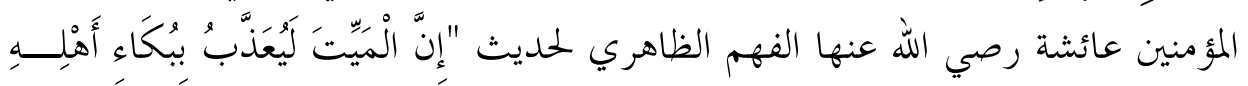

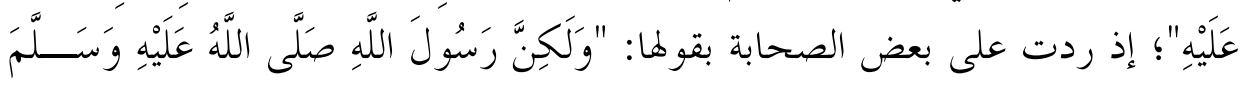

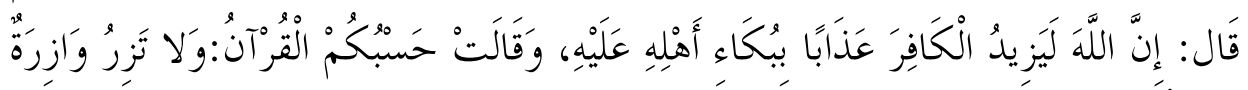

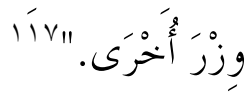

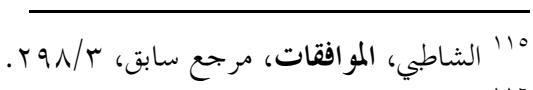

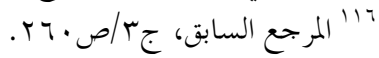

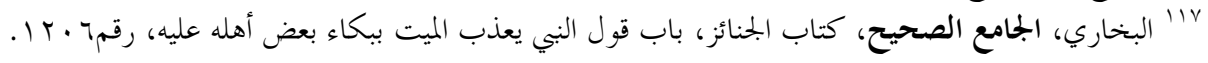




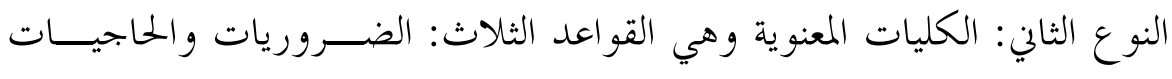

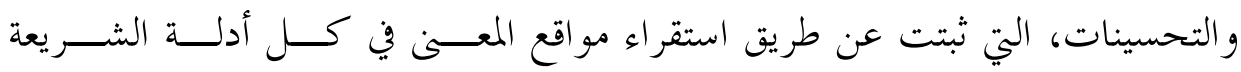

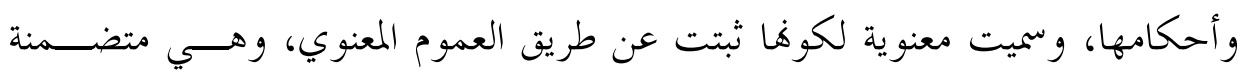

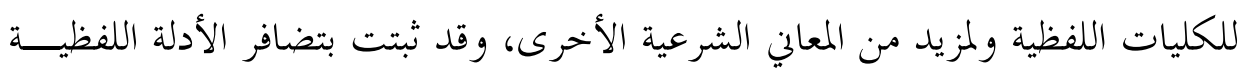

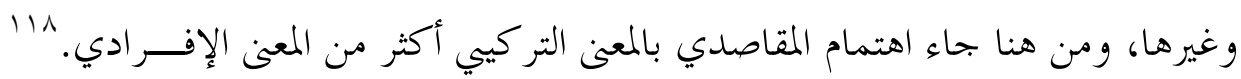

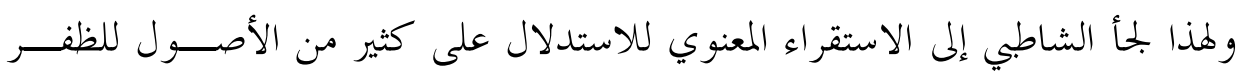

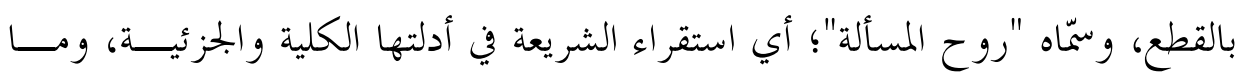
انطوت عليه هذه الأمور العامة، على حد الاستقراء المعنوي الذي لا يثبـــت بـــــليل

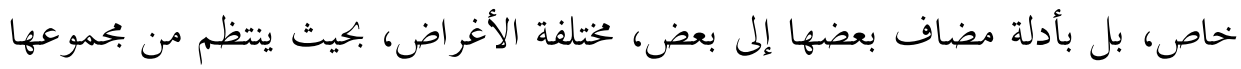

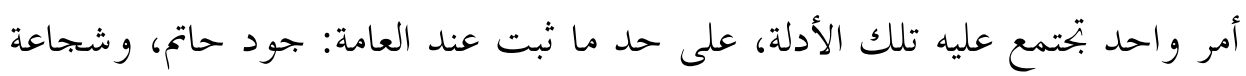
علي رضي الله عنه، وما أشبه ذلك.

خاتمة: - n - n

حاول البحث بسط مقاربة أهل المقاصد في تتبعهم للقصد في القرآن الكريم، فقدم

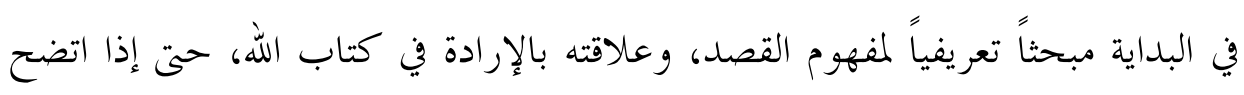
ذلك المفهوم خلص إلى التمييز بين نوعين من القصد في نصوص القرآن، فعند إجالـــة النظر فيما أبجزه المقاصديون في الباب، تراءى لنا أن الإرادة في القرآن الكــــيم علــى

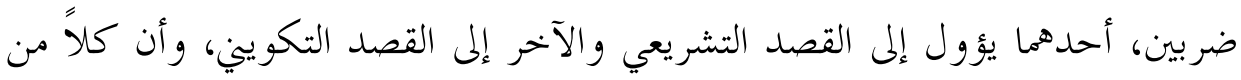

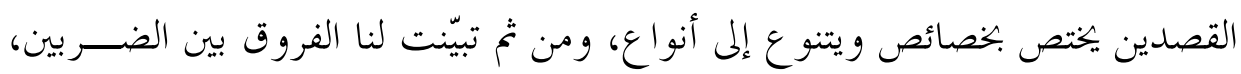

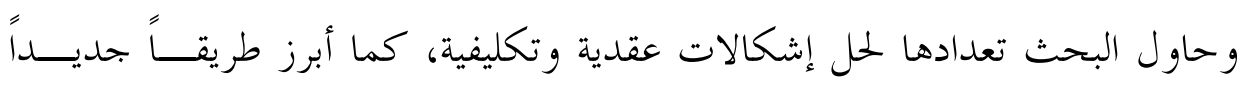
للكشف عن المقاصد التشريعية من خلال اعتبار نصوص القصد التكويني، وبعد ذلك

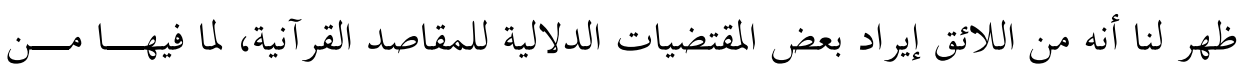
خدمة للموضوع على مستوى فهم أحسن لخطاب الله تعالى. 1'1 ينظر استدلال الشاطبي على أهمية المعنى التركيي في: الموافقات، مرجع سابق، / /7T. 
وقد أظهر لنا البحث نتائج عديدة منها أن عدم التمييز بين القصدين: التكـــيني

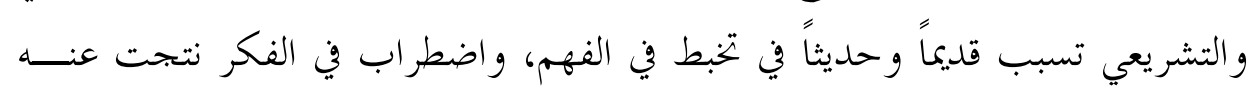

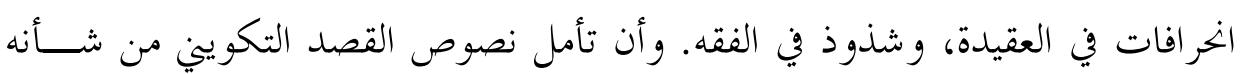

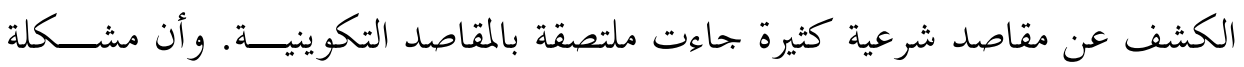

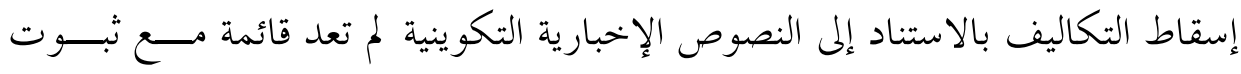

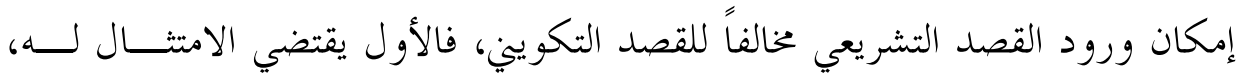

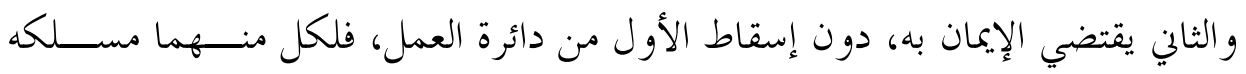

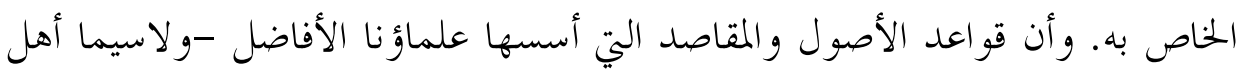

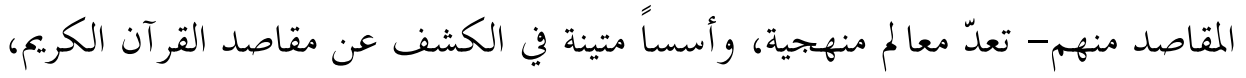

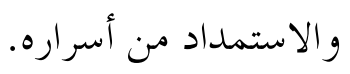

